\title{
45. OBLJETNICA RADA DRUŠTVA KNJIŽNIČARA SLAVONIJE, BARANJE I SRIJEMA
}

\author{
THE 45TH ANNIVERSARY OF THE SLAVONIA, \\ BARANJA AND SRIJEM LIBRARY ASSOCIATION
}

\author{
Marija Čačić \\ Knjižnica, Centar za kulturu Čepin \\ czk.cepin@gmail.com
}

\author{
UDK / UDC 061.2:02(091)DKSBS \\ Stručni rad / Professional paper \\ Primljeno / Received: 16. 1. 2021. \\ Prihvaćeno / Accepted: 13. 4. 2021.
}

\section{Sažetak}

Cilj. Cilj je rada prikazati osnivanje i razvoj Društva knjižničara Slavonije, Baranje i Srijema tijekom 45 godina, ponajviše u kontekstu razvoja hrvatskoga knjižničarstva i knjižničarskih društava te njegov doprinos knjižničarskoj struci i zajednici kako na regionalnoj tako i na nacionalnoj, ali i međunarodnoj razini.

Pristup/metodologija/dizajn. Istraživanju se pristupilo iščitavanjem objavljenih publikacija i dostupnih dokumenata. Na temelju podataka prikupljenih iz arhivskog gradiva Društva knjižničara Slavonije, Baranje i Srijema, Spomenice DKSBS-a, tiska te postojećih radova članova Društva, u radu se donose informacije o osnutku, načinima djelovanja i razvoja Društva te planovima za budući razvitak.

Rezultati. Rad daje detaljan uvid u povijesni razvoj Društva knjižničara Slavonije, Baranje i Srijema te ukazuje na njegovu povezanost s društvenim i kulturnim zbivanjima. Kao i knjižnice, i knjižničarske su se udruge tijekom svoga razvoja suočavale s brojnim poteškoćama poput nedostatka prostora i financijske potpore, ali su uvijek nastojala pravovaljano odgovoriti izazovima vremena i potrebama zajednice.

Originalnost/vrijednost. Rad predstavlja značajan doprinos povijesti knjižničarstva na području Republike Hrvatske na primjeru jedne lokalne knjižničarske udruge promatrane kroz društveni kontekst. Korišten je arhivski materijal, što radu daje do-

Vjesnik bibliotekara Hrvatske 64, 1(2021), 319-356

ISSN 0507-1925 
datnu vrijednost. Kako je prvi put dan takav pregled rada Društva, može poslužiti i kao osnova za daljnja istraživanja, ali može biti inspirativnim i za pisanje pregleda o povijesnom razvoju drugih regionalnih knjižničarskih društava.

Ključne riječi: Društvo knjižničara Slavonije, Baranje i Srijema, Hrvatsko knjižničarsko društvo, regionalna strukovna udruga knjižničara

\section{Abstract}

Aim. The aim of this paper is to present the establishment and development of the Slavonia, Baranja and Srijem Library Association (SBSLA) over the last 45 years, mostly in the context of the development of Croatian librarianship and librarian associations as well as its contribution to the librarian profession and community at the regional, national, and international levels.

Approach/methodology/design. The research was conducted by researching and reading available publications and documents. Based on data collected from the archives of the Slavonia, Baranja and Srijem Library Association, the register of the SBSLA, newspapers and the available works of the members of the Association, the paper presents information on the establishment, activity and development of the Association, as well as future development plans.

Results. The paper provides a detailed insight into the historical development of the Slavonia, Baranja and Srijem Library Association and points to its connection with various social and cultural events. Much like libraries, library associations have often faced a number of difficulties during their development, such as lack of space and financial support, but have always strived to respond adequately to the challenges of the times and the needs of the community.

Originality/value. The paper represents a significant contribution to the history of librarianship in Croatia on the example of a local library association observed in the social context. The archival material used for the research gives additional value to the paper. As this is the first time such an overview of the Association's work is given, it can also serve as a basis for further research. It can also be an inspiration for writing reviews on the historical development of other regional library associations.

Keywords: Croatian Library Association, regional professional librarian association, Slavonia, Baranja and Srijem Library Association 


\section{Uvod}

S ciljem zaštite i razvoja knjižničarske struke, osnovane su razne međunarodne knjižničarske udruge i organizacije te knjižničarska društva na državnoj i regionalnoj razini koja unapređuju i promiču knjižničarsku struku. Na odgovarajući je način predstavljaju u javnosti, organiziraju stručne skupove i izdaju časopise i druge stručne publikacije, sudjeluju u predlaganju i donošenju zakonskih propisa koji se tiču knjižničarske struke, zalažu se za profesionalni integritet knjižničnih djelatnika, potiču osnivanje i razvitak knjižnica, osiguravaju slobodan protok informacija kako bi se građanima omogućio slobodan i jednak pristup informacijama i građi, promiču pismenost, šire svijest o potrebi čuvanja kulturne baštine i sudjeluju u njezinoj zaštiti.

Najstarija je međunarodna organizacija na području informacijskih i dokumentacijskih metoda i tehnika te promocije interesa informacijskih stručnjaka i korisnika Međunarodna federacija za informacije i dokumentaciju (FID), ${ }^{1}$ uz koji se kroz proteklo stoljeće u prvom redu veže utemeljenje i razvoj Univerzalne decimalne klasifikacije kao najznačajnijeg klasifikacijskog sustava sadržajne obrade dokumenata radi skupljanja, organizacije i dostupnosti sveukupnog zabilježenog znanja. ${ }^{2}$

Danas je najveća i najznačajnija međunarodna strukovna organizacija za knjižničare i knjižnice IFLA (Međunarodni savez knjižničarskih društava i ustanova) ${ }^{3}$ koja knjižničarskim i informacijskim stručnjacima diljem svijeta omogućava razmjenu ideja, međunarodnu suradnju, istraživanja i razvoj na svim poljima knjižničarske djelatnosti i informacijskih službi, a ciljevi i programi organizacije ostvarivi su suradnjom i aktivnim uključivanjem njezinih članova. IFLA ima razvijenu nakladničku djelatnost u okviru koje objavljuje bibliografske standarde za opis različitih vrsta knjižnične građe, kao i standarde za rad pojedinih vrsta knjižnica, a služe kao uzor za izradu nacionalnih knjižničnih standarda. U IFLA Journalu

1 FID je akronim od francuskog Fédération Internationale d'Information et de Documentation. Riječ je o izdanku Instituta za bibliografiju koji su 1895. u Bruxellesu osnovali Belgijci Paul Otlet i Henri La Fontaine, a kasnije je sjedište organizacije u Hagu. Nagli razvoj informacijske tehnologije i dinamične promjene na području informacija i komunikacija doveli su u pitanje opstanak FID-a te je 2001. godine zbog materijalnih problema ukinuto djelovanje te organizacije. Usp. FID. Hrvatska enciklopedija, mrežno izdanje. Leksikografski zavod Miroslav Krleža, 2021. [citirano: 2021-04-08]. Dostupno na: https://www.enciklopedija.hr/natuknica.aspx?ID=19455.

2 Usp. FID. // Hrvatska enciklopedija. Zagreb: Leksikografski zavod Miroslav Krleža, 1999. 2001. sv. 3. Str. 623-624.

3 IFLA je akronim od engleskog International Federation of Library Associations and Institutions. Osnovana je 1927. godine u Edinburghu, a od 1971. sjedište joj je u Haagu u Kraljevskoj knjižnici. Djeluje kao nevladina neprofitna udruga koja zastupa interese knjižničara i njihovih korisnika, a stručni se rad odvija prema vrstama knjižnica i knjižničarskim djelatnostima u 7 osnovnih programa. Trenutno ima više od 1500 članova u više od 150 zemalja širom svijeta. Usp. IFLA. Hrvatska enciklopedija, mrežno izdanje. Leksikografski zavod Miroslav Krleža, 2021. [citirano: 2021-04-08]. Dostupno na: https://www.enciklopedija.hr/natuknica.aspx?id=26951. 
objavljuje članke o knjižničnim i informacijskim uslugama te društveno-političkim i ekonomskim pitanjima koja utječu na pristup informacijama u knjižnicama kao i izlaganja s godišnjih IFLA-inih konferencija. Monografska izdanja objavljuje u nizu IFLA Publications. ${ }^{4}$

Europska udruga knjižničnih, informacijskih i dokumentacijskih društava, EBLIDA, ${ }^{5}$ krovna je udruga više od 30 nacionalnih knjižničarskih, arhivskih, informacijskih i dokumentacijskih strukovnih društava i ustanova u Europi, sa sjedištem u Hagu.

EUCLI $^{6}$ je Europska udruga za knjižničarsko i informacijsko obrazovanje i istraživanje, a zastupa i pomaže suradnju i istraživanja obrazovnih ustanova koje školuju knjižničare, njihovog nastavničkog osoblja i studenata na području Europe. Pod nadzorom EUCLID-a održava se godišnji simpozij BOBCATSSS ${ }^{7}$ koji organiziraju studenti knjižničarstva s raznih sveučilišta Istočne i Zapadne Europe.

Osim međunarodnih, mnoštvo je strukovnih udruga knjižničara i informacijskih stručnjaka pojedinih zemalja, a jedna je od najstarijih i najvećih Američko knjižničarsko društvo (ALA) ${ }^{8} \mathrm{~S}$ velikom se tradicijom može pohvaliti i britansko Knjižničarsko društvo. ${ }^{9}$ I u susjednim su državama RH aktivna knjižničarska društva (Slovenija, Italija, Crna Gora, Bosna i Hercegovina, Srbija, Mađarska).

Hrvatsko knjižničarsko društvo (HKD) nacionalna je udruga hrvatskih knjižničara osnovana radi zaštite i promicanja knjižničarske struke i djelatnosti te

\footnotetext{
4 Usp. About IFLA. [citirano: 2021-04-05]. Dostupno na: https://www.ifla.org/about.

5 EBLIDA je akronim od engleskog European Bureau of Library, Information and Documentation Associations. Osnovana je1992. sa zadaćom da u Europskom parlamentu i drugim tijelima EU-a zastupa i promiče interese strukovnih društava i ustanova pri donošenju propisa kojima se uređuju područja autorskog prava, elektroničke trgovine, trgovine knjigom, politike prema knjizi i čitanju i kulturi općenito. Usp. EBLIDA. Hrvatska enciklopedija, mrežno izdanje. Leksikografski zavod Miroslav Krleža, 2021. [citirano: 2021-04-08]. Dostupno na: https://www.enciklopedija. $\mathrm{hr} /$ natuknica.aspx?id=16997.
}

6 EUCLID je akronim od engleskog European Association for Library and Information Education and Research.

7 BOBCATSSS je akronim koji opisuje mrežu sveučilišta. Slova označavaju početna slova gradova koji su pokrenuli BOBCATSSS 1993. g.: Budimpešta, Oslo, Barcelona, Kopenhagen, Amsterdam, Tampere, Stuttgart,Szombathely i Sheffield. Posljednjih nekoliko godina pridružili su im se i članovi sa Sveučilišta Boras, Riga, Kharkiv, Moskva, Tallinn, Toru, Varšava, Sofia, Ljubljana, Krakow, Bratislava, Prag, Osijek, Zadar, Berlin iPotsdam. Prvi je simpozij održan 1993. u Budimpešti, 2008. domaćin je bio Zadar, a 2019. Osijek.

8 ALA je akronim od engleskog American Library Association. Osnovano je u Philadelphiji 1876. godine, a danas je sjedište Društva u Chicagou i broji više od 65000 članova. Usp. About ALA. [citirano: 2021-04-08]. Dostupno na: http://www.ala.org/aboutala/.

9 Osnovano 1877. godine sa sjedištem u Londonu i okuplja više od 25000 članova s područja Velike Britanije i iz ostalih zemalja svijeta. Usp. Zabjan, A. Društvo knjižničara Slavonije i Baranje: osnutak, razvoj i djelovanje (1975. - 2007.): diplomski rad; Zadar: Sveučilište u Zadru, Odjel za knjižničarstvo, Izvanredni diplomski sveučilišni studij Informacijske znanosti - knjižničarstvo, 2008. Str. 5. 
osiguravanja profesionalnog integriteta knjižničnih djelatnika, a u svom se radu zalaže za najvišu razinu profesionalnog djelovanja i za razvoj demokratskih načela šire društvene zajednice. Osnovano je 14. ožujka 1940. godine pod nazivom Hrvatsko bibliotekarsko društvo (HBD) ${ }^{10}$ i od tada neprekidno djeluje, izuzevši razdoblje Drugog svjetskog rata i rane poratne godine. 1948. godine mijenja naziv u Društvo bibliotekara Hrvatske (DBH). Osnovane su sekcije, komisije i radne grupe, a važnu su ulogu imala i povjereništva koja se od 1950-ih godina osnivaju u većim gradovima te prerastaju u podružnice koje se ukidaju sedamdesetih godina dvadesetog stoljeća i osnivaju se regionalna društva. HKD ima veliku ulogu u donošenju propisa o knjižnicama i knjižničarskoj struci te podzakonskih akata (pravilnika, standarda, naputaka...) potrebnih za rad knjižnica i stručno napredovanje osoblja kao i same djelatnosti. Također ima važnu ulogu u obrazovanju i stalnom stručnom usavršavanju knjižničara. Od početka je aktivan član IFLA-e i sudjeluje u radu njezinih različitih tijela te doprinosi razvoju knjižničarstva u svijetu i podizanju razine knjižničarske struke u Hrvatskoj. Ima razvijenu nakladničku djelatnost (stalna, povremena i prigodna izdanja te Vjesnik bibliotekara Hrvatske - VBH i HKD Novosti, čije su mrežne inačice dostupne na mrežnim stranicama Društva). Za postignute rezultate u knjižničarstvu zaslužnim članovima dodjeljuje Kukuljevićevu povelju i Nagradu Eva Verona. Statutom $^{11}$ je HKD definiran kao nezavisna, nevladina i neprofitna udruga koja djeluje na području Republike Hrvatske, sa sjedištem u Zagrebu, u Nacionalnoj i sveučilišnoj knjižnici, a članovi su Društva 16 regionalnih knjižničarskih društava te pojedinci knjižničarske struke. Jedno je od regionalnih društava Društvo knjižničara Slavonije, Baranje i Srijema (DKSBS). ${ }^{12}$

\section{Povijesni pregled}

Na 2. skupštini Društva bibliotekara Hrvatske, održanoj 10. prosinca 1950., Glavnom se odboru stavlja u zadatak osnivanje povjereništva za sjeveroistočnu Hrvatsku, a prvi se oblik organiziranog djelovanja knjižničara na tom području bilježi u svibnju 1951. godine, kada je osnovano Povjereništvo Društva biblioteka Hrvatske - Osijek. Prva je povjerenica bila prof. Marija Malbaša (slika 1), voditeljica knjižnice Muzeja Slavonije, koju predanim radom podiže na nivo općeznanstvene knjižnice, unatoč poslovima tajnice i blagajnice Društva, ustrajno promičući struku. Nemjerljiv je njezin doprinos istraživanju kulturne povijesti

10 Usp. Živković, D. Osnutak i prve godine rada: pogled u arhiv. // Hrvatsko knjižničarsko društvo: 14. III. 1940. - 14. III. 2000.: spomenica. Zagreb: Hrvatsko knjižničarsko društvo, 2000. Str. 10.

11 Usp. Statut Hrvatskog knjižničarskog društva. [citirano: 2021-03-01]. Dostupno na: http:// www.hkdrustvo.hr/hr/statut/.

12 Usp. Regionalna društva. [citirano: 2020-06-03] Dostupno na: https://www.hkdrustvo.hr/ hr/o_nama/regionalna_drustva/. 
Osijeka i Slavonije, za što je 1968. godine nagrađena Kukuljevićevom poveljom, najvećim priznanjem u knjižničarskoj struci. ${ }^{13}$

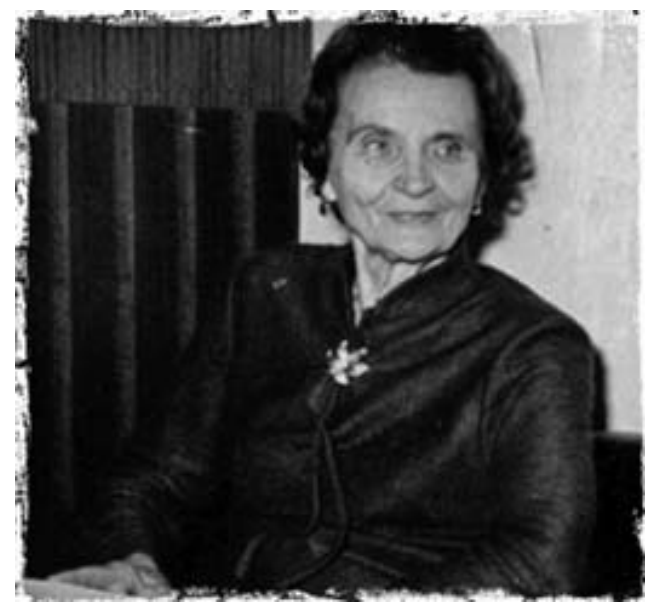

Slika 1. Marija Malbaša

Ako bi se osnivanje Povjereništva računalo kao dan osnivanja Društva, kao što to neka regionalna knjižničarska Društva čine, tada bi Društvo knjižničara Slavonije, Baranje i Srijema 2021. godine slavilo 70. rođendan.

Spomenuto je Povjereništvo 1967. preraslo u Podružnicu (više od 10 članova), okosnicu na kojoj je 21. svibnja 1975. utemeljeno Društvo knjižničara Slavonije i Baranje. Predsjednicom Podružnice Društva bibliotekara Hrvatske - Osijek izabrana je Marija Nikolašević (bibliotekarka Visoke poljoprivredne škole), tajnicom Slavica Rešetar (bibliotekarka Ekonomskog fakulteta), a blagajnicom Nada Heil (knjižničarka Gradske knjižnice). ${ }^{14}$ Podružnica je djelovala od 21. travnja 1967. do 21. svibnja 1975. godine. Marija Nikolašević bila je predsjednica Podružnice od 1967. do 1973. godine, a od 1973. do 1975. godine Nada Bojanić. Podružnica je podržavala razvoj kulturnog i društvenog života u Osijeku te su članovi redovno posjećivali, ali i organizirali razne kulturne manifestacije. Podružnica je, kao i Povjereništvo, okupljala samo djelatnike knjižnica iz Osijeka, međutim početkom 1970-ih godina sve se više ukazivala potreba za povezivanjem bibliotekara cjelokupne Slavonije i Baranje. Stoga su, nakon godišnje Skupštine održane 21. ožujka 1973. godine, na prijedlog Pavla Blažeka, direktora Gradske knjižnice Osijek, na sastancima Podružnice sudjelovali i predstavnici knjižnica iz Belog Manastira, Čepina, Đakova, Josipovca, Podravske Slatine, Slavonskog

13 Usp. Vinaj, M. Društvo knjižničara Slavonije, Baranje i Srijema. // Bibliotekar 2(2017), str. 60.

14 Usp. Pismohrana Društva. Izvještaj o održanom godišnjem sastanku od 22. IV. 1967. 
Broda, Valpova, Vinkovaca i Vukovara te zajednički rješavali probleme s kojima se struka susretala. ${ }^{15}$

U Osijeku je 16. svibnja 1975. održan sastanak Inicijativnog odbor za osnivanje novog regionalnog društva u sastavu od 7 članova: Zeina Petošić (Slavonska Požega), Ana Vuković (Vinkovci), Duško Ciganović (Vukovar), Laura Merki (Beli Manastir), Pavle Blažek (Osijek), Nada Bojanić (Osijek) i Marija Vrljević (Osijek). ${ }^{16}$ Inicijativni je odbor na temelju preporuka Upravnog odbora Hrvatskog bibliotekarskog društva i zaključaka s proširenog sastanka Podružnice, održanog 8. travnja 1975. godine, te pismene suglasnosti pojedinih knjižnica, donio odluku o ukidanju Podružnice i osnivanju regionalnog društva koje će okupljati knjižnične djelatnike s područja Slavonije i Baranje. Donesen je i Prijedlog Statuta Društva, dogovoren je naziv i sjedište Društva, organi upravljanja i termin Osnivačke skupštine. ${ }^{17}$ Prva je predsjednica Društva knjižničara Slavonije i Baranje (DKSB) bila Nada Bojanić (slika 2) iz Gradske i sveučilišne knjižnice u Osijeku, ${ }^{18}$ koja je na tu funkciju izabrana zahvaljujući iskustvu stečenom vođenjem Podružnice HBD-a Osijek od 1973. - 1975 godine.

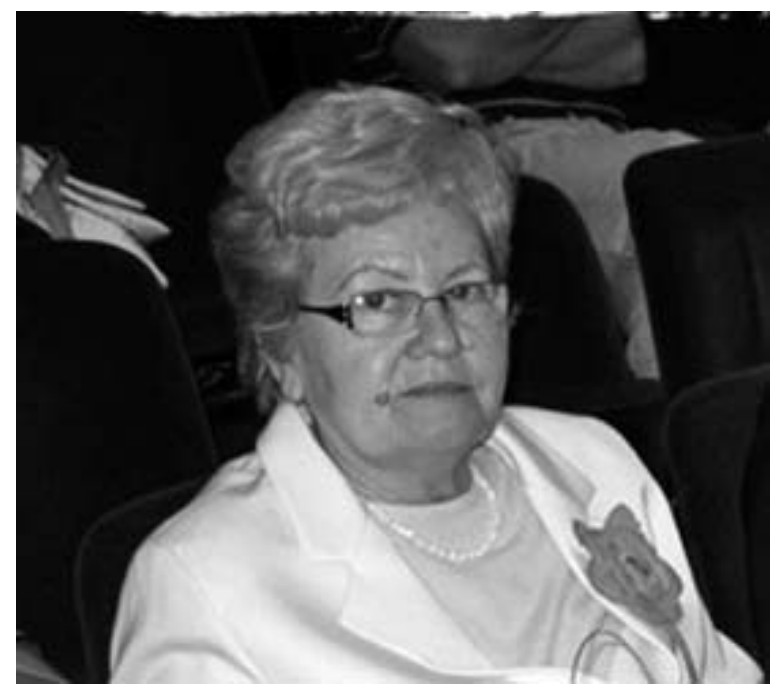

Slika 2. Nada Bojanić (prva predsjednica DKSB-a)

15 Usp. Pismohrana Društva. Izvještaj o radu Podružnice Hrvatskog bibliotekarskog društva Osijek od 21. III. 1973. do 21. V. 1975. godine.

16 Usp. Pismohrana Društva. Zapisnik sa sastanka Inicijativnog odbora za osnivanje Društva bibliotekara Slavonije i Baranje održanog 16. V. 1975. u Gradskoj knjižnici Osijek.

17 Usp. Rad Društva bibliotekara Slavonije i Baranje: 1975-1985. Osijek: Društvo bibliotekara Slavonije i Baranje, 1985. Str. 12.

18 Usp. Spomenica Društva knjižničara Slavonije i Baranje: 1975.-2005. Osijek: Društvo knjižničara Slavonije i Baranje, 2009. Str. 16. 
Time je zaključeno 24-godišnje razdoblje u radu knjižničara Osijeka, a pokrenuto novo u kojem će doći do bliže suradnje s knjižničarima na području Slavonije i Baranje u rješavanju zajedničkih problema. Prema riječima Pavla Blažeka: „Podružnica zapravo ne prestaje djelovati, već reorganizirana, u širem sastavu, nastavlja i dalje s radom." 19

Na području Slavonije i Baranje djelovala je i podružnica HBD-a Vinkovci, Vukovar, Županja i Ilok, ali se o njezinu radu ne zna mnogo jer je dokumentacija uništena u požaru Vinkovačke knjižnice 1991. godine. Međutim, na temelju izlaganja Vere Erl povodom 30. obljetnice Društva knjižničara Slavonije i Baranje, 2005. godine, poznata je aktivnost Narodne knjižnice i čitaonice Vinkovci u Društvu bibliotekara Hrvatske još 1963. godine, kada je ravnateljica Ljubica Šrajer izabrana za drugu potpredsjednicu DBH-a. Također je poznata inicijativa te knjižnice za osnivanjem podružnice koja bi obuhvatila Vukovar, Osijek, Županju i Vinkovce. 1971. godine osnovan je Ogranak HBD-a Vukovar koji je 1973. godine prerastao u podružnicu sa sjedištem u Vinkovcima. ${ }^{20}$ Podružnica HBD Vinkovci, Vukovar, Županja i Ilok djelovala je svega četiri godine (1971. - 1975.) i u tom kratkom razdoblju nije se uspjela u potpunosti razviti, pa je osnivanje Društva bibliotekara Slavonije i Baranje za nju, ustvari, predstavljalo novi početak. ${ }^{21}$

Društvo knjižničara Slavonije i Baranje osnovano je na Osnivačkoj skupštini u Osijeku, 21. svibnja 1975. godine ${ }^{22}$ (slika 3). Društvu je pristupilo 12 slavonsko-baranjskih općina: Beli Manastir, Donji Miholjac, Đakovo, Našice, Orahovica, Osijek, Podravska Slatina, Slavonska Požega, Valpovo, Vinkovci, Vukovar i Županja. Nisu pristupili Nova Gradiška ${ }^{23}$ i Slavonski Brod. U Glavni su odbor HBD-a izabrane Nada Bojanić i Marija Brkić, a u Nadzorni odbor Pavle Blažek. Osnivanje Društva popraćeno je člankom Ljerke Antonić u Glasu Slavonije 22. svibnja 1975. godine pod naslovom „Promicanje ugleda bibliotekarstva: održana Osnivačka skupština Društva bibliotekara Slavonije i Baranje““. ${ }^{24}$

\footnotetext{
19 Isto, str. 24. Pavle Blažek bio je direktor osječke Gradske i sveučilišne knjižnice od 1967. do 1988. godine.

20 Isto

21 Isto, str. 25.

22 Isto, str. 29.

23 Nepoznato je kada je pristupila Nova Gradiška, ali se na popisu članova iz 1985. godine navode četiri njezina člana.

24 Usp. Pismohrana Društva. Antonić, Lj. Promicanje ugleda bibliotekarstva. // Glas Slavonije od 22. svibnja 1975.
} 


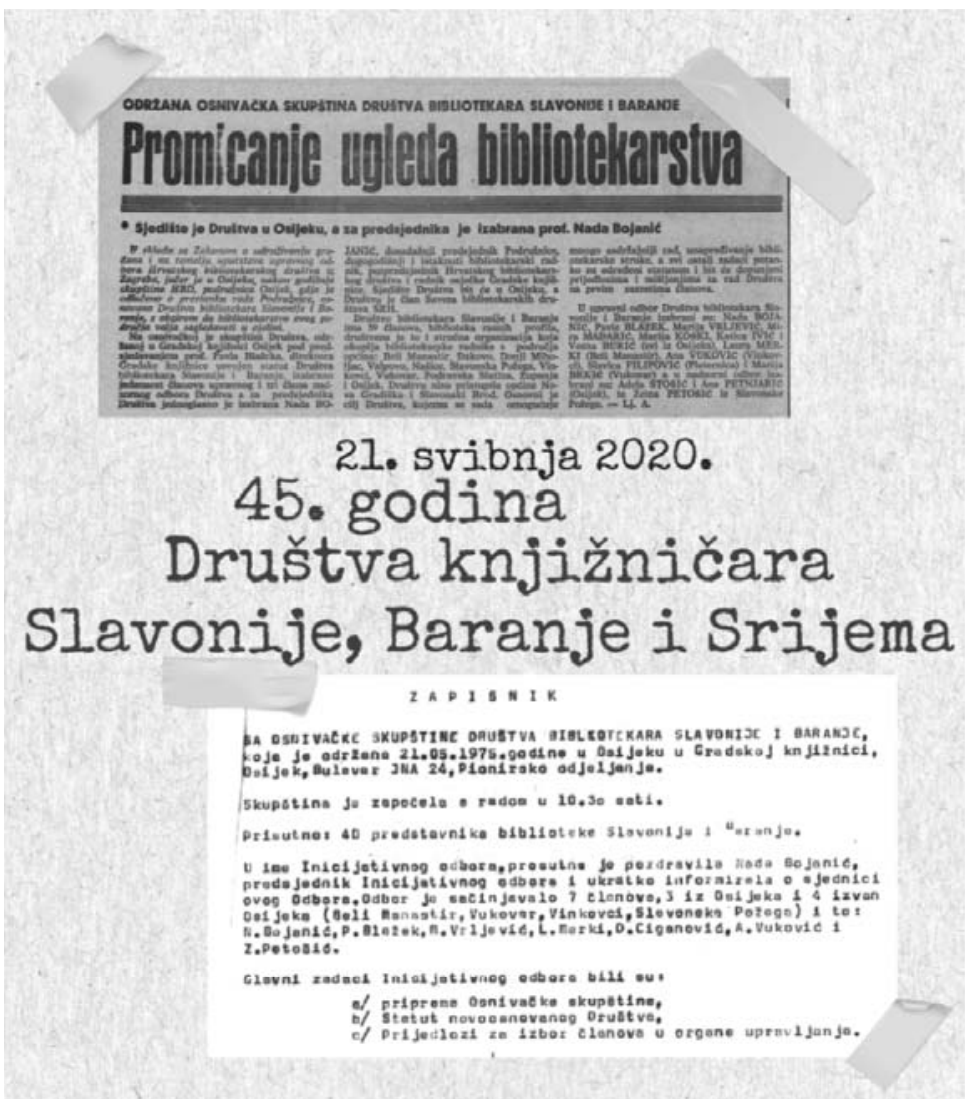

Slika 3. Članak Lj. Antonić u Glasu Slavonije i Zapisnik s osnivačke skupštine

Na 20. redovnoj godišnjoj skupštini Hrvatskoga bibliotekarskog društva, održanoj 9. i 10. lipnja 1975. godine u Kumrovcu, Društvo bibliotekara Slavonije i Baranje primljeno je u Savez društava bibliotekara SR Hrvatske, ${ }^{25}$ a 11. srpnja 1975. godine, nakon što je upućen zahtjev Republičkom sekretarijatu za unutrašnje poslove socijalističke Republike Hrvatske, Društvo je Rješenjem II/4 broj: UP/Io-203/1-1975. upisano u Registar udruženja građana pod rednim brojem 888 i tako steklo svojstvo pravne osobe te moglo početi s radom. ${ }^{26}$ Pod tim nazivom Društvo djeluje sve do 2016. godine kada se, na inicijativu članova iz Vukovarsko-srijemske županije, nazivu pridodaje i Srijem te Društvo mijenja ime u Društvo knjižničara Slavonije, Baranje i Srijema.

25 Usp. XX. redovna godišnja skupština Hrvatskoga bibliotekarskog društva. // Vjesnik bibliotekara Hrvatske 21, 1-4(1975), str. 44.

26 Pismohrana Društva 
„Izmjenama Statuta Društva tijekom 2016. godine izmijenjen je i službeni naziv Društva koji od Izvanredne Skupštine u ožujku 2017. godine nosi i službeni naziv Društvo knjižničara Slavonije, Baranje i Srijema. ${ }^{\text {"27 }}$

Riječ je o nezavisnoj, nevladinoj i neprofitnoj strukovnoj udruzi koja djeluje na području knjižničarstva i informacijskih znanosti, ${ }^{28}$ a okuplja knjižničare zaposlene u svim tipovima knjižnica triju županija: Osječko-baranjske, Vukovarsko-srijemske i Požeško-slavonske. Od osnutka joj je osnovna djelatnost okupljanje članova i razvoj struke kroz skupštine, stručne i znanstvene skupove, predavanja, okrugle stolove, izložbe i radionice te suradnja s Hrvatskim knjižničarskim društvom. Društvo ima razvijenu nakladničku djelatnost, a od 2006. godine dodjeljuje Povelju „Marija Malbaša“ kao priznanje najistaknutijim članovima. Pravna je osoba upisana u Registar udruga Republike Hrvatske ${ }^{29}$ s osnovnim ciljem djelovanja na nacionalnom i kulturnom području knjige i knjižničarstva te unapređenju knjižničarske struke i djelatnosti. Sjedište je u Osijeku u Gradskoj i sveučilišnoj knjižnici (GISKO).

\section{Tijela Društva i upravljanje Društvom}

Rad se Društva odvija prema Statutu ${ }^{30}$ koji se mijenjao i dopunjavao sukladno promjenama i dopunama Statuta HKD-a i zakonskih propisa. Usporedbom Statuta Društva iz različitih razdoblja vidljive su značajne promjene naziva, područja djelovanja, ciljeva i djelatnosti. Zadaci, ciljevi i djelatnosti Društva definirani su različito, prilagođeni promjenama i zahtjevima u struci i širem društvenom okruženju, ali je uvijek naglasak na unaprjeđivanju knjižničarske struke i knjižnične djelatnosti. Prvi Statut, s Osnivačke skupštine 1975. godine, nažalost nije sačuvan.

Članovi Društvom upravljaju neposredno ili preko izabranih predstavnika, a tijela su Društva: Skupština, Predsjednik i dva potpredsjednika, Upravni odbora i Nadzorni odbor. Najviše je tijelo Skupština koju čine svi članovi Društva te tako neposredno sudjeluju u radu Društva. Skupštine se održavaju u različitim gradovima i općinama na području djelovanja Društva (slika 4), što doprinosi zbližavanju i upoznavanju članova kao i knjižnice i mjesta domaćina. Skupštine Društva održavane su redovito, s iznimkom od 1991. g. do 1994. g., kada zbog ratnih zbivanja na području Slavonije i Baranje nije održana niti jedna.

\footnotetext{
27 Vinaj, M. Nav. dj., str. 62.

28 Usp. Statut Društva knjižničara Slavonije, Baranje i Srijema. [citirano: 2020-06-04]. Dostupno na: http://www.dksb.hr/dokumenti/statut/.

29 Usp. Registar udruga Republike Hrvatske. [citirano: 2020-12-27]. Dostupno na: https://registri.uprava.hr/\#!udruga-detalji/swcBAAEAAQGxZHJ1xaF0dm8ga25qacW-bmnEjWFyYSBzbGF2b25pamUsIGJhcmFuamUgaSBzcmlqZW1hAAAAAAAAAACfCQEAAQIAAAABHAAAAAAAAAABAQFvaeICAdqBAg.

${ }^{30}$ Statut donosi Skupština Društva.
} 


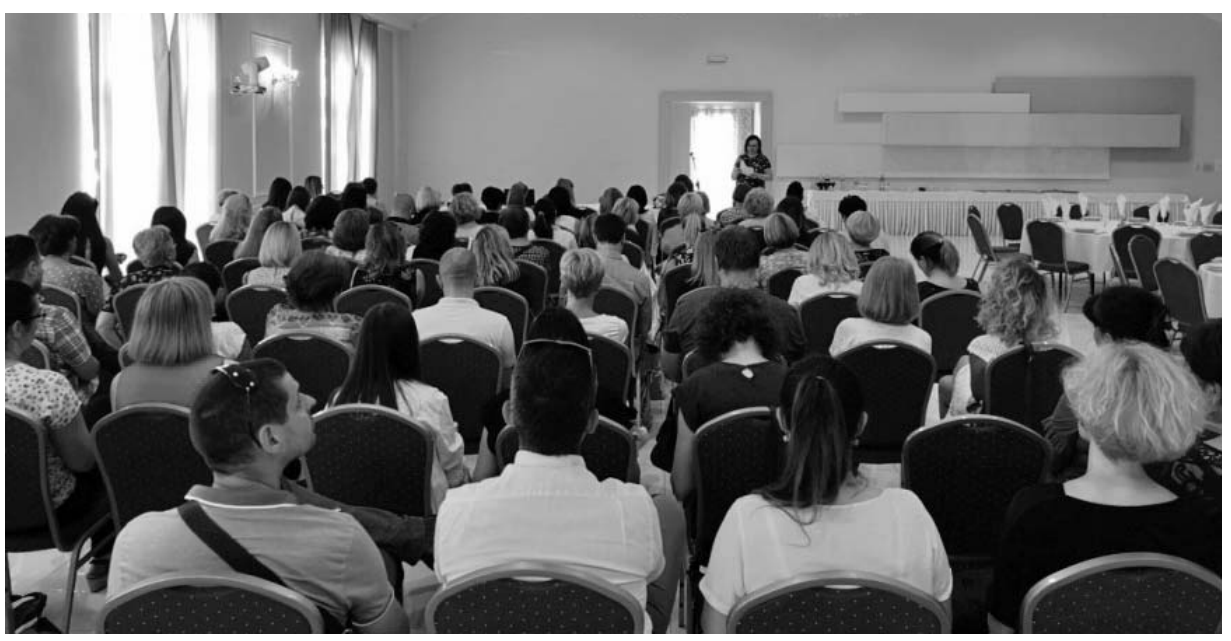

Slika 4. 22. Redovna Skupština u Čepinu 2018. godine

Predsjednik Društva, u skladu sa Statutom predstavlja i zastupa Društvo, organizira i vodi rad i poslovanje Društva. Imenuje ga Skupština na dvije godine. Do sada su svi predsjednici savjesno i odgovorno obavljali svoje zadaće te, brinući o kontinuitetu, nastavljali aktivnosti prethodnika osuvremenjujući ih novim (tablica 1).

Tablica 1. Predsjednici Društva od osnutka do danas ${ }^{31}$

\begin{tabular}{|l|l|}
\hline Nada Bojanić & $1975 .-1977 ., 1977 .-1978 ., 1979 .-1981$. \\
\hline Pavle Blažek & $1981 .-1983 ., 1983 .-1985$. \\
\hline Vera Erl & $1985 .-1987 ., 1987 .-1989 ., 1989 .-1991$. \\
\hline Vjekoslav Bizjak & $1991 .-1994$. \\
\hline Kata Ivić & $1994 .-1996$. \\
\hline Ljubica Radman & $1996 .-1998$. \\
\hline Silva Pavlinić & $1998 .-2000 ., 2000 .-2002$. \\
\hline Emilija Pezer & $2002 .-2004 ., 2004 .-2006$. \\
\hline Andrea Božić & $2006 .-2008 ., 2008 .-2010$. \\
\hline Marina Vinaj & $2010 .-2012 ., 2012 .-2014$. \\
\hline Vlatka Surma Szabo & $2014 .-2016$. \\
\hline Marija Čačić & $2017 .-2019 ., 2019 .-2021$. \\
\hline
\end{tabular}

31 Usp. Predsjednici Društva. [citirano 2020-06-04]. Dostupno na: http://www.dksb.hr/povijest/. 
Upravni je odbor (UO) (slika 5) izvršno tijelo Društva i najviše tijelo upravljanja između dviju Skupština, a ima 11 članova (uključujući predsjednika Društva) koje bira Skupština. Zastupljeni su predstavnici svih vrsta knjižnica i najmanje su dva člana izvan sjedišta Društva. Biraju dva potpredsjednika, od kojih je drugi uvijek izvan Osijeka. Upravni odbor organizira rad Društva, donosi godišnji program rada kao i financijski plan, odlučuje o primanju novih članova i prijedlozima za isključenje i brisanje članstva, predlaže visinu članarine, priprema nacrte akata, priprema i saziva Skupštinu, podnosi izvještaj o radu, osniva odbore i komisije, organizira stručne skupove, pokreće izdavanje stručnih publikacija i sl. Najveću je pozornost Upravni odbor posvećivao stručnom radu i usavršavanju članova u svrhu čega je osnivao pomoćna tijela: odbore, sekcije i komisije koje su planove i programe rada usklađivale sa sekcijama i komisijama HKD-a. Od osnutka Društva mijenjao se broj i naziv, kao i sastav pojedinih odbora, komisija i sekcija, međutim pratili su pitanja svog područja rada i vodili računa o kontinuitetu rada Društva te davali prijedloge za rješenja te tako doprinosili unapređenju knjižničarske struke. ${ }^{32}$ Posljednjih je godina Upravni odbor sjednice organizirao i izvan sjedišta kako bi se upoznali i s novouređenim knjižnicama (2017. godine u Knjižnici Centra za kulturu Čepin - slika 6, 2019. godine u Knjižnici Muzeja Slavonije - slika 7).

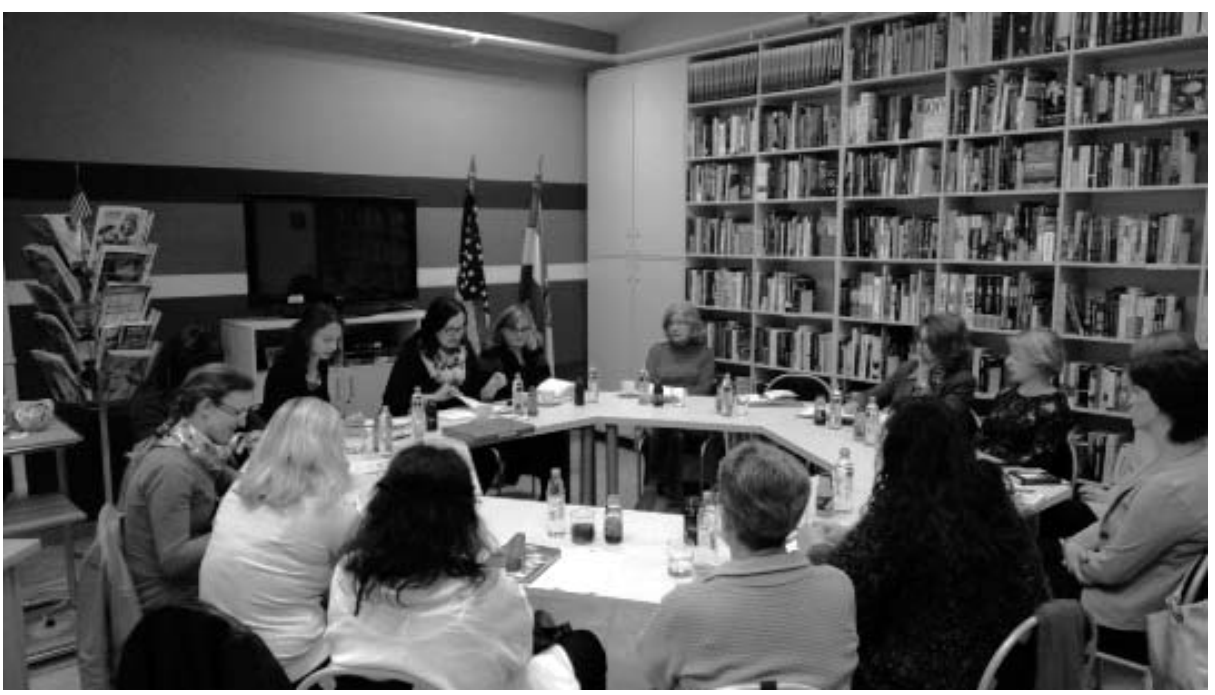

Slika 5. Sjednica Upravnog odbora u GISKO-u

32 Usp. Spomenica Društva. Nav. dj., str. 36-37. 
M. Čačić: 45. OBLJETNICA RADA DRUŠTVA KNJIŽNIČARA SLAVONIJE, BARANJE I ...

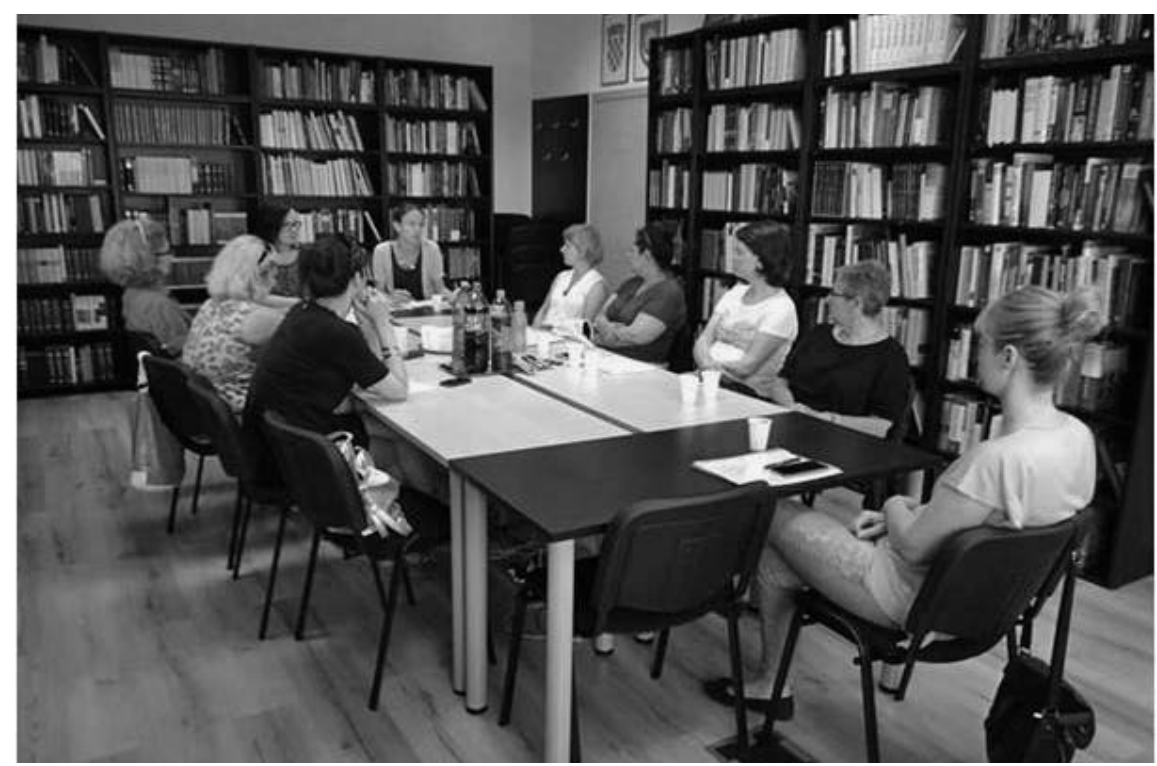

Slika 6. UO u Knjižnici CZK Čepin

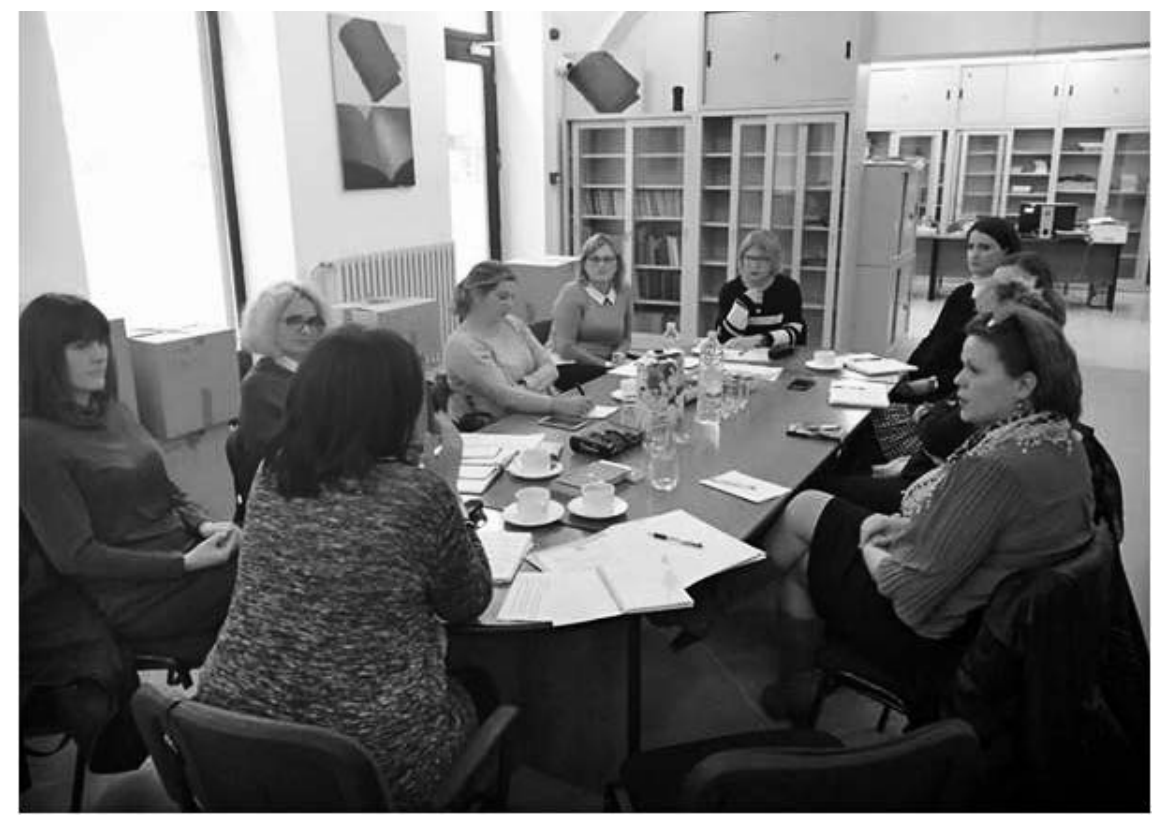

Slika 7. UO u Knjižnici Muzeja Slavonije 
Nadzorni odbor kontrolira zakonitost rada i financijskog poslovanja Društva. Sastoji se od triju članova i dvaju zamjenika, a bira ga Skupština na dvije godine.

\section{1. Članstvo}

Članstvo u Društvu može biti redovno, počasno, pridruženo i potporno ${ }^{33} \mathrm{Od}$ prva tri člana (Marija Malbaša, Danica Krulj i Alica Kovačević) u vrijeme Povjereništva 1951. godine, broj je porastao na 19 u 1967. godini, a do većeg povećanja broja članova dolazi osnivanjem visokoškolskih ustanova u Osijeku od 1960. godine jer su sve imale knjižnice sa zaposlenim barem jednim knjižničarem. ${ }^{34} \mathrm{Za}$ vrijeme osnivanja 1975. godine, Društvo je brojalo 57 članova, ${ }^{35}$ a u 2007. godini 232 člana. Revizijom je članstva utvrđeno da Društvo 2016. godine broji 138 članova jer su knjižničari iz Virovitičko-podravske te Brodsko-posavske županije osnovali svoja regionalna društva. ${ }^{36}$

Danas Društvo okuplja 197 članova - 103 člana iz narodnih knjižnica, 12 iz specijalnih, 25 iz visokoškolskih, 21 osnovnoškolskih, 8 srednjoškolskih, 11 ostalih (profesori Odsjeka za informacijske znanosti) i 17 umirovljenika. ${ }^{37}$ Pojedini su članovi Društva aktivni u radu komisija i sekcija HKD-a (poneki i njihovi predsjednici), a neki su bili i potpredsjednici HKD-a. Članovi Društva redovno sudjeluju na stručnim skupovima u organizaciji Hrvatskoga knjižničarskog društva i na međunarodnim knjižničnim konferencijama (skupštine HKD-a; savjetovanja za narodne knjižnice; seminari Arhivi, Knjižnice, Muzeji; Dani specijalnih i visokoškolskih knjižnica; Proljetna škola školskih knjižničara; Knjižnice u procjepu; LIDA; BOBCATSSS, i dr.).

Članstvom u Društvu, uz rad u matičnoj ustanovi, razmjenom primjera dobre prakse, stjecanjem novih vještina i osobnim rastom i razvojem dostiže se profesionalna izvrsnost. Stalnim stručnim usavršavanjem omogućeno je napredovanje u struci i stjecanje viših zvanja. Svaki član ima mogućnost birati i biti biran u tijela Društva, a aktivizmom se osnažuje osjećaj pripadnosti knjižničarskoj zajednici (HKD-u). Moguće je postati dobitnikom Povelje Marija Malbaša (slika 8) ili, na prijedlog ili uz podršku Društva, priznanja Knjižnica godine.

\footnotetext{
33 Usp. Statut Društva. Nav. dj.

34 Usp. Spomenica Društva. Nav. dj., str. 17.

35 Usp. Pismohrana Društva. Zapisnik sa Osnivačke Skupštine Društva bibliotekara Slavonije i Baranje koja je održana u Osijeku, 21. 5. 1975. god.

36 Usp. Vinaj, M.Nav. dj., str. 62.

37 Usp. Pismohrana Društva. Opisno godišnje izvješće o radu DKSBS-a u razdoblju od 1. siječnja do 31. prosinca 2019.
} 


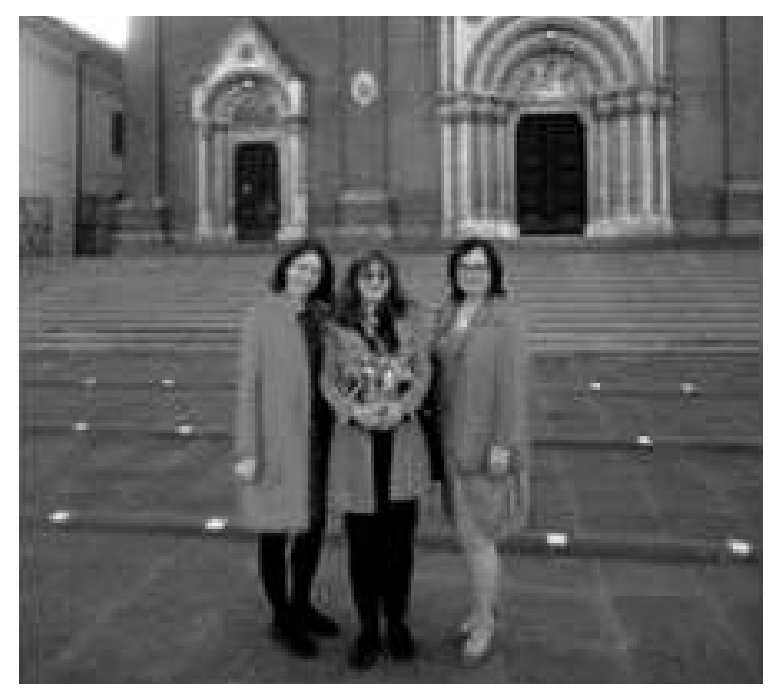

Slika 8. Dodjela Povelje M. Malbaša 2019. god. $^{38}$

Članovima organizacijskih i programskih odbora moguće je sufinanciranje sudjelovanja na stručnim skupovima, a članovima umanjena kotizacija za određene stručne skupove. Međugeneracijskim povezivanjem i umrežavanjem stvaraju se preduvjeti za osmišljavanje zajedničkih projekata s kolegama iz drugih knjižnica i baštinskih ustanova. Promoviranjem struke u javnosti ostvaruje se ugled osobe, ali i ustanove u kojoj radi. Stručnim putovanjima moguće je vidjeti i upoznati knjižnice na području Slavonije, Baranje i Srijema, kao i knjižnice i ostale institucije kulture diljem Europe. Članovi ostvaruju popust pri kupovini knjiga u knjižarama Nova i Školska knjiga u Osijeku.

\section{Izdavačka djelatnost Društva}

Od osnutka je Društvo među svoje ciljeve postavilo poticanje stručnog i znanstvenog rada članova opredjeljujući se za aktivan doprinos razvoju vlastite struke. Već je se na sastanku Inicijativnog odbora za osnivanje Društva, održanom 16. svibnja 1975. godine, Pavle Blažek založio da u Statutu nove udruge bude i stavak o izdavačkoj djelatnosti. ${ }^{39}$

Prigodom obilježavanja desete obljetnice rada Društvo izdaje prvu stručnu publikaciju Rad Društva bibliotekara Slavonije i Baranje: 1975-1985., a za iz-

38 Na fotografiji slijeva nadesno: tajnica DKSBS-a Marijana Špoljarić Kizivat, dobitnica Povelje Ljiljana Krpeljević (GISKO) i predsjednica DKSBS-a Marija Cačić (ispred Katedrale u Đakovu jer je skupština DKSBS-a 2019. godine održana na Katoličkom bogoslovnom fakultetu u Đakovu).

39 Usp. Spomenica Društva. Nav. dj., str. 79. 
davanje su bili zaduženi Danka Vidović i Pavle Blažek. Povodom 45. obljetnice rada, spomenica je digitalizirana. ${ }^{40}$ Osim službenih dokumenata (Statut, sastav i sjednice Upravnog odbora i drugih tijela Društva), sadrži i izvještaje sa skupština, plenuma, stručnih putovanja, izvještaje o stručnom radu Društva i članova Društva, a objavljena su i imena svih tadašnjih članova.

Dvije godine kasnije Upravni odbor pokreće izdavanje publikacije Informacije Društva bibliotekara Slavonije i Baranje ${ }^{41}$ koje je uređivala Vera Erl. Od listopada 1987. do travnja 1991. godine objavljeno je sedam brojeva. Zamišljene su kao obavijesno glasilo i svojevrsna kronika događanja u Društvu i knjižničarstvu s ciljem informiranja članova o radu Društva i zbivanjima u struci. Umnažale su se priručnom tehnikom, šapirografom uz pomoć i donaciju tvrtke Saponia Osijek i, unatoč skromnoj izvedbi, odigrale važnu ulogu kao prethodnica najvažnijem izdavačkom pothvatu Društva - časopisu Knjižničarstvo, a znatno su utjecale i na pojavu sličnih glasila drugih regionalnih društava.

Tijekom Domovinskog rata i u poratnim godinama gasi se izdavačka djelatnost, ali je Društvo već 1997. godine pokrenulo stručno glasilo pod nazivom Knjižničarstvo: glasnik Društva knjižničara Slavonije i Baranje (slika 9).

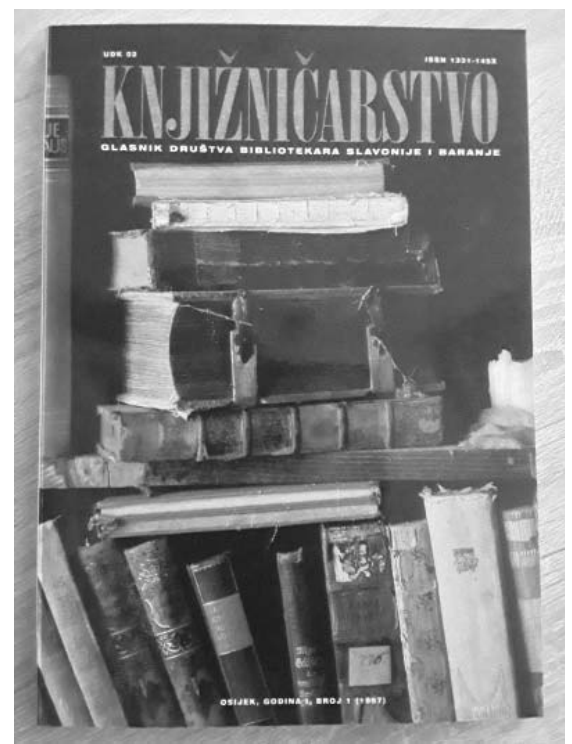

Slika 9. Prvi broj tiskanog časopisa Knjižničarstvo

40 Rad Društva bibliotekara Slavonije i Baranje: 1975-1985 / [urednik Danka Vidović]. Osijek: Društvo bibliotekara Slavonije i Baranje, 1985. [citirano: 2021-03-01]. Dostupno na: https://issuu. com/dksbs/docs/rad_dksbs_1975-1985.

${ }^{41}$ Usp. Spomenica Društva. Nav. dj. Str. 79. 


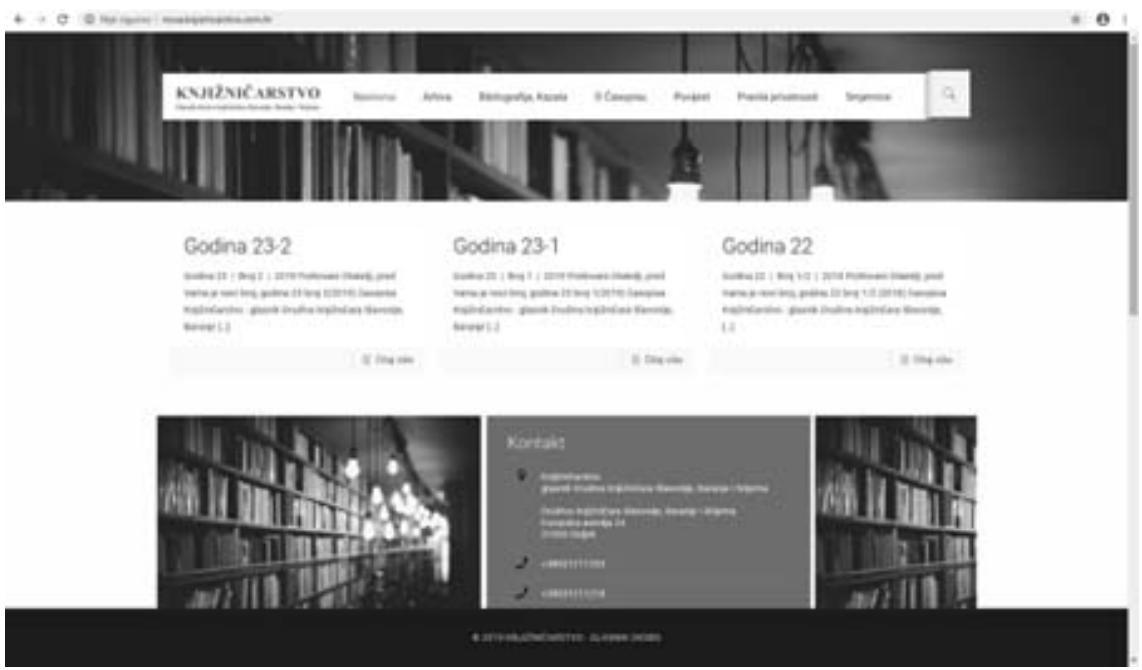

Slika 10. Mrežna stranica časopisa Knjižničarstvo

Prvi je broj Knjižničarstva objavljen 22. svibnja 1997. godine. Urednik prvih četiriju godišta bio je Dragutin Katalenac, urednica sedmog i osmog godišta Silva Pavlinić, a naslijedila ju je Marina Vinaj, urednica od devetog do dvanaestog godišta. Sva su godišta izdavana u tiskanom obliku. Godine 2005. Knjižničarstvo se prvi put pojavljuje u elektroničkom obliku, a digitalizirani su pojedini članci za koje je Uredništvo pribavilo autorska prava. Od 2012. do 2016. godine urednica Svjetlana Mokriš, uz pomoć članice Uredništva Sande Hasenay, pokreće elektroničku inačicu časopisa ${ }^{42}$ (ISSN 1848-5308) (slika 10), koju dalje razvija urednica Merien Hadrović. Časopis izlazi dvaput godišnje. Od lipnja 2020. godine brojeve objavljene u elektroničkoj inačici moguće je prelistati i u ISSUU formatu poput novina ili kataloga ${ }^{43}$ a novi su brojevi i suvremeno redizajnirani. Kvaliteta tekstova te stručna i znanstvena izvrsnost osigurani su sustavom dvostruke ano-

42 Elektronička je inačica časopisa dostupna na poveznici https://nova.knjiznicarstvo.com.hr/. Objavljuju se originalni stručni i znanstveni radovi s područja informacijskih znanosti. Sadržajno pokriva teme informacijskih znanosti (informacijskih sustava i informatologije, komunikologije, knjižničarstva, muzeologije, arhivistike, leksikografije i enciklopedistike) te kulturološke teme - stručnih i znanstvenih područja među kojima su danas granice sve propusnije. Sastoji se od dvaju dijelova: stručno-znanstvenog i obavijesnog. Stručno-znanstveni dio časopisa nije lokalno/ regionalno ograničen, poželjni su stručni članci s područja čitave Hrvatske. U obavijesnom dijelu predstavlja knjižnice Slavonije i Baranje te daje vijesti, ocjene i prikaze o radu Društva. Časopis čine rubrike: Predgovor urednika, Članci, O slavonsko-baranjskim knjižnicama (Iz povijesti slavonsko-baranjskih knjižnica, Predstavljamo slavonsko-baranjske knjižnice), Putevima svjetskih knjižnica, Vijesti iz knjižnica, Ocjene i prikazi, Osobne vijesti. Usp. O časopisu. [citirano: 202006-09]. Dostupno na: http://nova.knjiznicarstvo.com.hr/o_casopisu/.

43 Usp. ISSUU. [citirano: 2020-06-09].Dostupno na: http://nova.knjiznicarstvo.com.hr/prelistajte-knjiznicarstvo/. 
nimnosti recenzentskog postupka. Ovisno o prilikama, recenzenti mogu biti i inozemni. Kategoriju rada predlažu recenzenti, a konačnu odluku donosi Uredništvo. Zahvaljujući navedenom, od 2019. godine Knjižničarstvo udovoljava potrebnim kriterijima i dostupno je na portalu hrvatskih znanstvenih i stručnih časopisa $\mathrm{Hr}$ $\check{c} a k^{44}$. Dostupni su brojevi izvorno objavljeni u elektroničkom obliku (od godišta 2009/2010.) kao i rubrika recenziranih članaka ili radova sa stručnih i znanstvenih skupova.

Povodom 30. obljetnice rada i djelovanja Društvo je izdalo Spomenicu Društva knjižničara Slavonije i Baranje: 1975. - 2005. (slika 11)

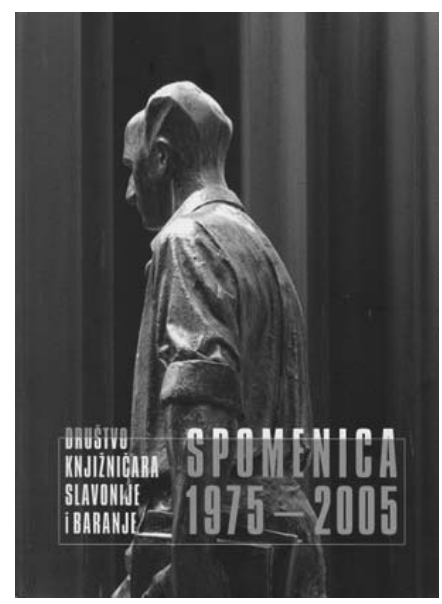

Slika 11. Spomenica DKSB-a: 1975. - 2005.

Pod uredničkom palicom Marine Vinaj, voditeljice Knjižnice Muzeja Slavonije, detaljno je, na temelju arhivske dokumentacije, dan pregled rada Društva i aktivnosti članova te iznimna i ustrajna borba za priznavanje knjižničarske struke. Poglavlja Zapisi o prošlosti Društva knjižničara Slavonije i Baranje; Društvo knjižničara Slavonije i Baranje (1975. -2005.); Napredovanja u struci i Nagrade i odlikovanja priredila je Ljubica Radman, poglavlja Stručne publikacije Društva i Ratna stradanja knjižnica Slavonije i Baranje Dragutin Katalenac, poglavlja Studij Knjižničarstva; Sjećanja i Doprinos Marije Malbaše istraživanju kulturne povijesti Osijeka i Slavonije Vera Erl. Ljiljana Krpeljević priredila je popis Članova Društva, a Ljubica Radman Bibliografiju objavljenih stručnih radova članova Društva od 1953. do 2005. godine. O značaju Spomenice za Društvo, najbolje svjedoče riječi njezine urednice Marine Vinaj:

„Tri desetljeća zajedništva iznjedrila su ovu Spomenicu koja je, dragi čitatelji, više od spomena na negdašnje djelovanje Društva knjižniča-

${ }^{44}$ Usp. Hrčak. [citirano: 202-06-09]. Dostupno na: https://hrcak.srce.hr/knjiznicarstvo. 
ra Slavonije i Baranje, uspjehe, skupštine, druženja, nagrade, ... Ovo je priča o ljudima, na žalost mnogih od njih više nema, o ljudima koji su stvorili i još uvijek stvaraju začudnu vezu ljudi i knjiga, svih njezinih pojavnosti, ne posustajući pred izazovima novih medija,. Ovo je priča namijenjena, prije svega, budućim knjižničarima, informatolozima, čitačima i zaljubljenicima u pero.“45

Iznimno je važno naglasiti zajedništvo ljudi, marljivih članova Društva, čiji doprinos Spomenica čuva, ali i vezu s novim generacijama koje dolaze i nastavljaju tamo gdje su prethodnici stali.

S ciljem upoznavanja javnosti s osnovnim podacima te sadržajima i uslugama koje nude, Upravni je odbor pokrenuo i izdavanje niza vodiča kroz knjižnice Slavonije i Baranje (po županijama), ali je do sada objavljen samo Vodič kroz knjižnice Požeško-slavonske županije 1997. godine. ${ }^{46}$ Od 2020. godine na mrežnim je stranicama Društva dostupan Vodič kroz knjižnice Društva knjižničara Slavonije,

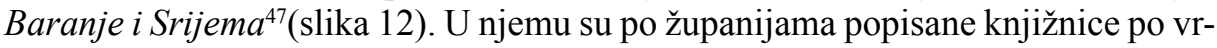
stama, a odabirom pojedine poveznice pristupa se mrežnim stranicama knjižnice.

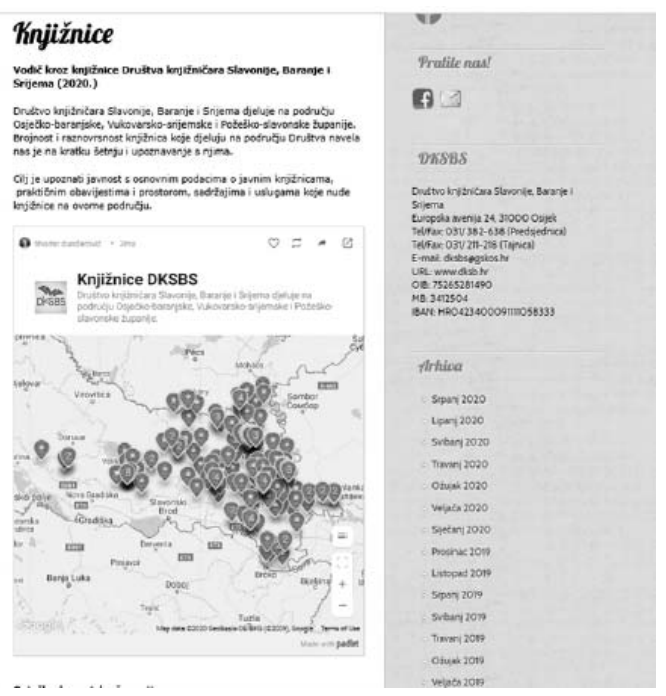

Slika 12. Mrežni vodič kroz knjižnice DKSBS-a

\footnotetext{
45 Vinaj, M. Uvodna riječ. // Spomenica Društva knjižničara Slavonije i Baranje: 1975. - 2005. Osijek: Društvo knjižničara Slavonije i Baranje, 2009. Str. 7.

46 Spomenica Društva. Nav. dj., str. 38.

47 Usp. Vodič kroz knjižnice Društva knjižničara Slavonije, Baranje i Srijema. [citirano 2020-0629]. Dostupno na: http://www.dksb.hr/knjiznice/.
} 


\section{Aktivnosti Društva}

\subsection{Stručni skupovi}

Upravni je odbor Društva, u suradnji sa svojim sekcijama i komisijama, Hrvatskim knjižničarskim društvom, udrugama i ustanovama iz srodnih djelatnosti organizirao zapažena predavanja (slika 13), stručne skupove, predstavljanja knjiga, izložbe, seminare, savjetovanja, okrugle stolove i sl., na kojima su gosti-predavači bili istaknuti stručnjaci iz područja knjižničarstva, ali i pojedini članovi našeg Društva. Takvim stručnim aktivnostima Društvo promiče značaj knjižničarske struke te pridonosi jačanju stručnih kompetencija svojih članova.

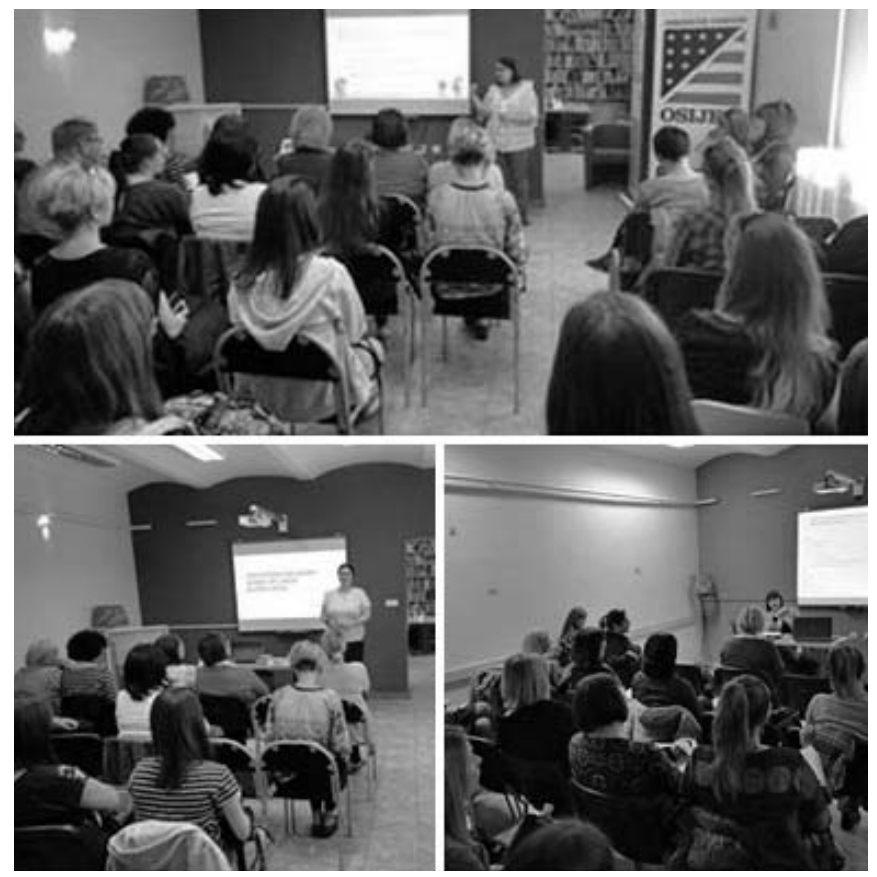

Slika 13. Predavanja u organizaciji DKSBiS-a

Društvo je pokretač i organizator okruglog stola Zavičajni fondovi i zbirke $u$ knjižnicama panonskog prostora (slika 14) kojemu je od 2020. godine suorganizator Komisija za zavičajne zbirke kojoj je na taj način ujedno ponovo potaknuta aktivnost. 2021. godine održa će se 4. okrugli stol o zavičajnosti s međunarodnim sudjelovanjem (uz domaćine, Mađarska, Srbija, BiH).

Knjižnice, članice DKSBS-a, aktivno sudjeluju u različitim stručnim projektima. S obzirom na sve zagađeniji okoliš, posljednjih su godina atraktivne Zelene knjižnice za zelenu Hrvatsku s ciljem edukacije javnosti i razvoja svijesti o zna- 
čaju očuvanja prirodnoga okoliša, recikliranja i korištenja platnenih ili papirnatih vrećica umjesto plastičnih, odnosno o održivom društvu i nužnosti zaštite okoliša kroz stručna predavanja, promocije knjiga, radionice, izložbe i projekcije filmova. Uz Filozofski fakultet Osijek i Klub studenata informacijskih znanosti Libros, udrugu „Sport za sve“, Knjižnicu Centra za kulturu Čepin, Gradsku i sveučilišnu knjižnicu Osijek i osječki ogranak Hrvatskog čitateljskog društva, Društvo knjižničara Slavonije, Baranje i Srijema organiziralo je 2019. godine prvu biciklijadu (slika 15) na istoku Hrvatske u znak podrške nacionalnoj kampanji za osobe s teškoćama čitanja i disleksijom I ja želim čitati.

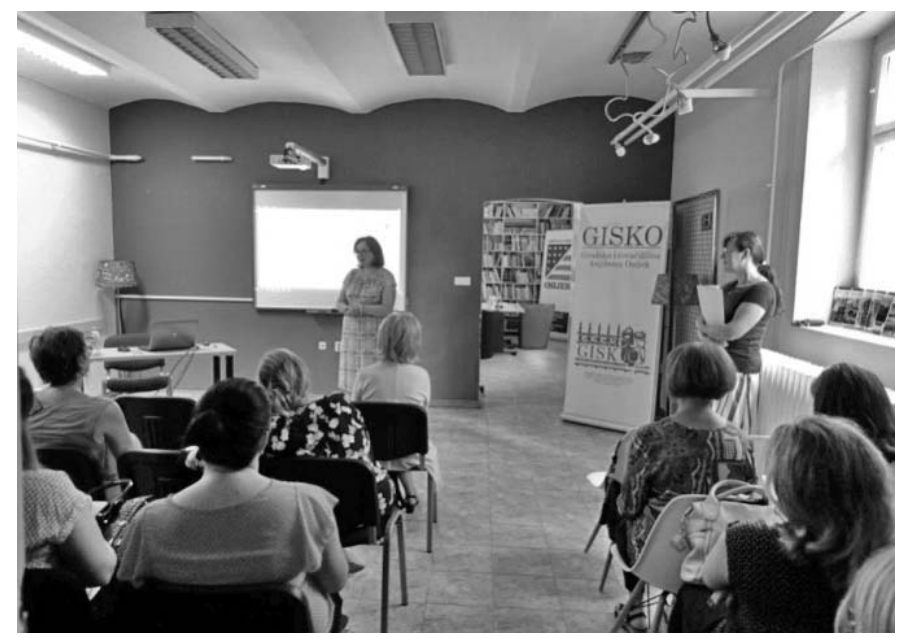

Slika 14. Okrugli stol o zavičajnosti 2018. god.

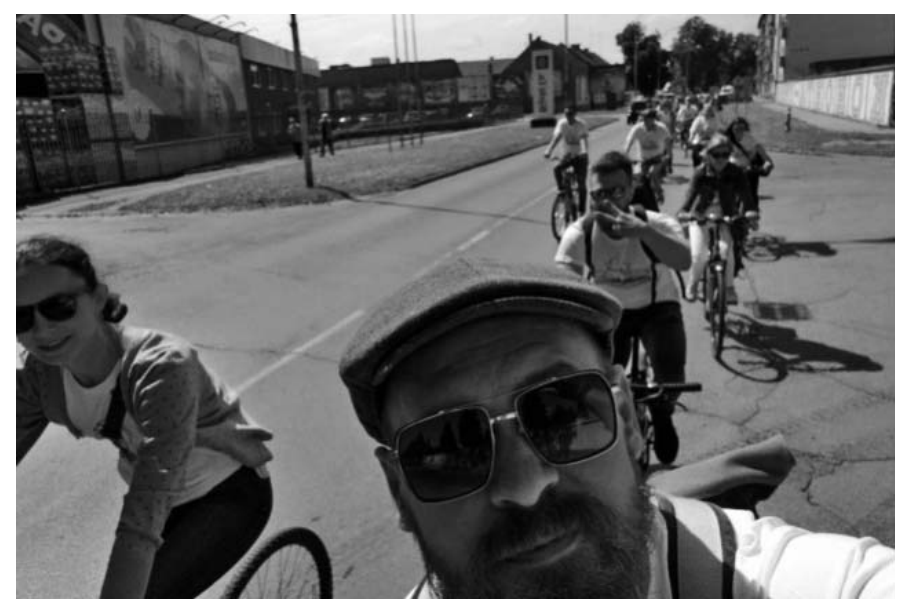

Slika 15. Biciklijada Osijek - Čepin 2019. god. 
Društvo potiče i aktivno se uključuje u obilježavanje manifestacije Mjesec hrvatske knjige u organizaciji Knjižnica grada Zagreba raznim stručnim i edukativnim predavanjima vezanim uz knjigu i knjižničnu djelatnost. Bila je velika hrabrost odabir, tada još okupiranog, Vukovara za otvaranje Mjeseca hrvatske knjige '97., čemu se odazvao veliki broj knjižničara iz cijele Hrvatske. Hrvatsko je knjižničarsko društvo tako bilo prva strukovna udruga koja je organizirano, pod zaštitom UNTAES-a, ušla u razrušeni Vukovar. ${ }^{48}$

\subsection{Obrazovanje i znanstveni rad}

Društvo knjižničara Slavonije i Baranje s tadašnjim Pedagoškim fakultetom i Gradskom i sveučilišnom knjižnicom Osijek pokretač je otvaranja studija knjižničarstva na Pedagoškom fakultetu. ${ }^{49} \mathrm{Za}$ to je najzaslužnija mr. sc. Vera Erl koja je, kao predsjednica Društva, još 1986. godine pokrenula pitanje otvaranja dodiplomskog studija bibliotekarstva, međutim zbog Domovinskoga rata taj priželjkivani cilj ostvario se tek u akademskoj 1998./99.godini. Od akademske 1999./2000. pokrenut je i izvanredni (dopunski dvogodišnji) studij te je tako podignuta obrazovna razina knjižničara, što je bio velik poticaj bržem razvoju modernog knjižničarstva na području Slavonije i Baranje ${ }^{50}$ Praktičnom nastavom studenata u knjižnicama ostvarena je dvostrana dobrobit: studenti su usvojili praktična znanja i stekli iskustvo, a knjižice su dobile dodatne prijeko potrebne kadrove sa svježim znanjima i vještinama.

Brojni su članovi Društva, uz stručni rad, iznimno aktivni i u znanstvenim istraživanjima, što pokazuje velik broj magistara i doktora znanosti ${ }^{51}$ (Prilog 1), a brojni su članovi promaknuti u viša zvanja.

\subsection{Suradnja}

Jedna je od smjernica rada Društva suradnja sa srodnim strukovnim udrugama i institucijama u Hrvatskoj i inozemstvu. Društvo surađuje i s drugim regionalnim knjižničarskim društvima u zemlji, s Hrvatskim čitateljskim društvom, s kulturnim ustanovama na svom području, medijima. Suradnje i stručne ekskurzije, uz obavezan obilazak knjižnica i baštinskih ustanova, omogućavaju razmjenu ideja i primjera dobre prakse te upoznavanje i zbližavanje članstva. Tako brže kolaju

\footnotetext{
48 Isto., str. 39-40.

49 Pavlinić, S. Društvo knjižničara Slavonije i Baranje. // Hrvatsko knjižničarsko društvo: 14. III. 1940. - 14. III. 2000.: spomenica. Zagreb: Hrvatsko knjižničarskodruštvo, 2000. Str. 65-66.

50 Spomenica Društva. Nav. dj., str. 38.

51 Do 2004. godine popis magistarskih i doktorskih radova preuzet je iz Spomenice Društva knjižničara Slavonije i Baranje: 1975. - 2005. Osijek: Društvo knjižničara Slavonije i Baranje, 2009. Str. 136.-137., a ostalo iz Izvješća o radu (dostupno na: http://www.dksb.hr/dokumenti/izvjesca-o-radu/), časopisa Knjižničarstvo, rubrike Osobne vijesti (dostupno na: http://nova.knjiznicarstvo.com. hr/arhiva/) te pretraživanjem po autoru kroz CROLIST, Skupni katalog hrvatskih knjižnica.
} 
informacije o najnovijoj stručnoj literaturi i najsuvremenijim trendovima u knjižničarstvu, a njihovom implementacijom u praksi ostvaruje se brži razvoj knjižničarske struke.

Suradnja s HKD-om ostvaruje se sudjelovanjem predstavnika/delegata na skupštinama te $\mathrm{u}$ radu predsjednika Društva na sjednicama Glavnog odbora HKD-a. Članovi su također aktivno uključeni u rad odbora, sekcija i komisija HKD-a. Osim toga, aktivno su sudjelovali u izradi standarda za pojedine vrste knjižnica, kao i Zakona o knjižnicama. Istaknuti su članovi bili članovi Savjeta za biblioteke, Hrvatskoga knjižničnog vijeća (HKV), Povjerenstva HKV-a za dodjelu viših zvanja, Povjerenstva Ministarstva kulture za nakladništvo i otkup knjiga. Društvo je bilo domaćinom nekoliko skupština HKD-a (tablica 2).

Tablica 2. Društvo „domaćin“ skupština HKD-a

\begin{tabular}{|l|l|}
\hline Osijek & 1979. godine \\
\hline Bizovačke toplice & 1994. godine \\
\hline Osijek & 2012. godine \\
\hline
\end{tabular}

Povjeravanjem organizacije skupštine HKD-a 1994. godine ovom regionalnom Društvu u Bizovačkim toplicama, kada su pojedini dijelovi bili još okupirani i kada je Osijek bio udaljen od crte razdvajanja svega nekoliko kilometara, HKD je pružio veliku podršku Društvu i cijeloj istočnoj Hrvatskoj.

Društvo je ostvarilo dobru suradnju i s Hrvatskim čitateljskim društvom čija je 5. godišnja skupština održana u Osijeku 2000. godine. Niz godina Društvo surađuje s knjižničarskim udruženjima u Austriji, Bosni i Hercegovini, Mađarskoj, Slovačkoj i Sloveniji. Razvoju međunarodne suradnje veliki je doprinos dao Odsjek za informacijske znanosti Filozofskog fakulteta u Osijeku, koji je zahvaljujući međunarodnim vezama svojih profesora organizirao brojna gostovanja uglednih knjižničarskih stručnjaka, profesori su i studenti sudjelovali na međunarodnim skupovima, a pokrenut je i međunarodni seminar Knjižnice u digitalnom dobuLIDA u Dubrovniku.

Za Društvo je osobito značajna suradnja s Mađarskim knjižničarskim društvom, koja je neposrednija i intenzivnija od 1998. godine, kada je u Pečuhu održana Hrvatsko-mađarska knjižnična konferencija na kojoj je ukazano na moguće oblike suradnje (i društava, ali i knjižnica). 2004. godine je, nakon susreta knjižničara u Osijeku i Pečuhu, u Pečuhu održana Hrvatsko-mađarska konferencija knjižničara Zajedno s dvije strane granice te je potpisan Sporazum o suradnji. ${ }^{52}$

Kako bi se razvijala međunarodna suradnja, posjetile knjižnice diljem Hrvatske, stekla nova radna iskustva, upoznale nove sredine i produbila suradnja čla-

$52 \quad$ Spomenica Društva. Nav. dj., str. 41. 
nova, Društvo je od svoga osnutka organiziralo stručna putovanja. Putovalo se u Mađarsku (Pečuh, Szombathely, Budimpešta), Austriju (Beč i Nacionalna knjižnica Austrije, Željezno), Češku (Prag), Italiju (Venecija, Firenza, Bologna, Padova, Pisa, San Gimignano i Siena), Njemačku (Salzburg i München, dvorci Bavarske i Bayerische Staatbibliothek u Münchenu), Bosnu i Hercegovinu (Sarajevo), Srbiju (Subotica - slika 16, Beograd - slika 17), Sloveniju (Maribor). Na stručnim je putovanjima primarno bilo posjetiti knjižnice, osobito nacionalne, ali i gradske, sveučilišne, samostanske, te druge kulturne znamenitosti. Biblioteci u Željeznom, gdje žive Gradišćanski Hrvati i u Subotici, gdje također ima Hrvata, darovane su knjige na hrvatskom jeziku.

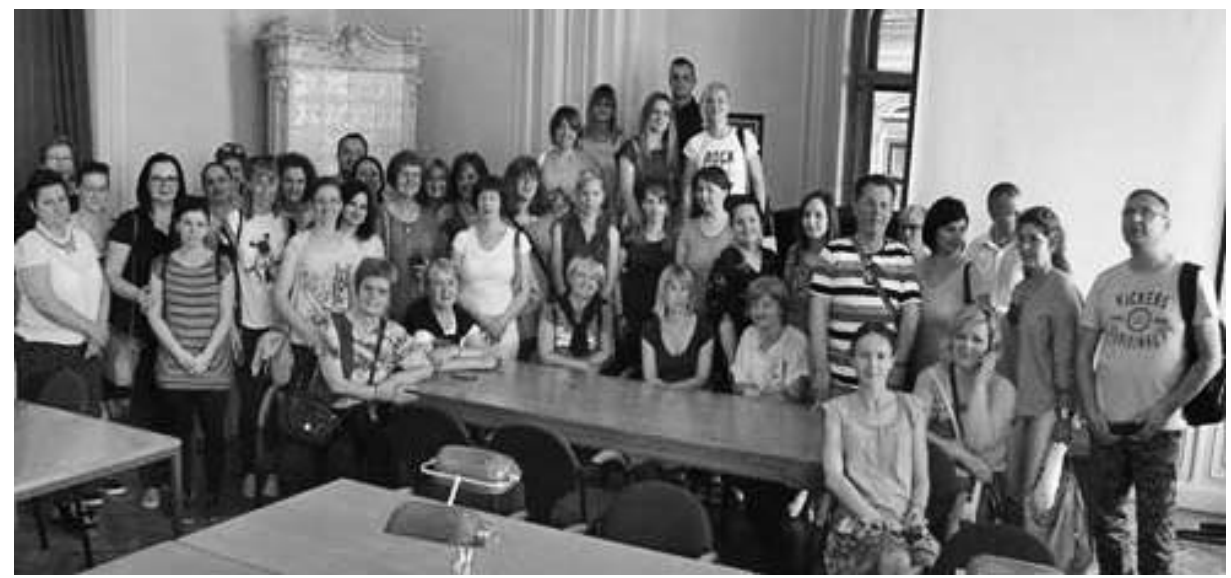

Slika 16. U Subotici 2017. god.

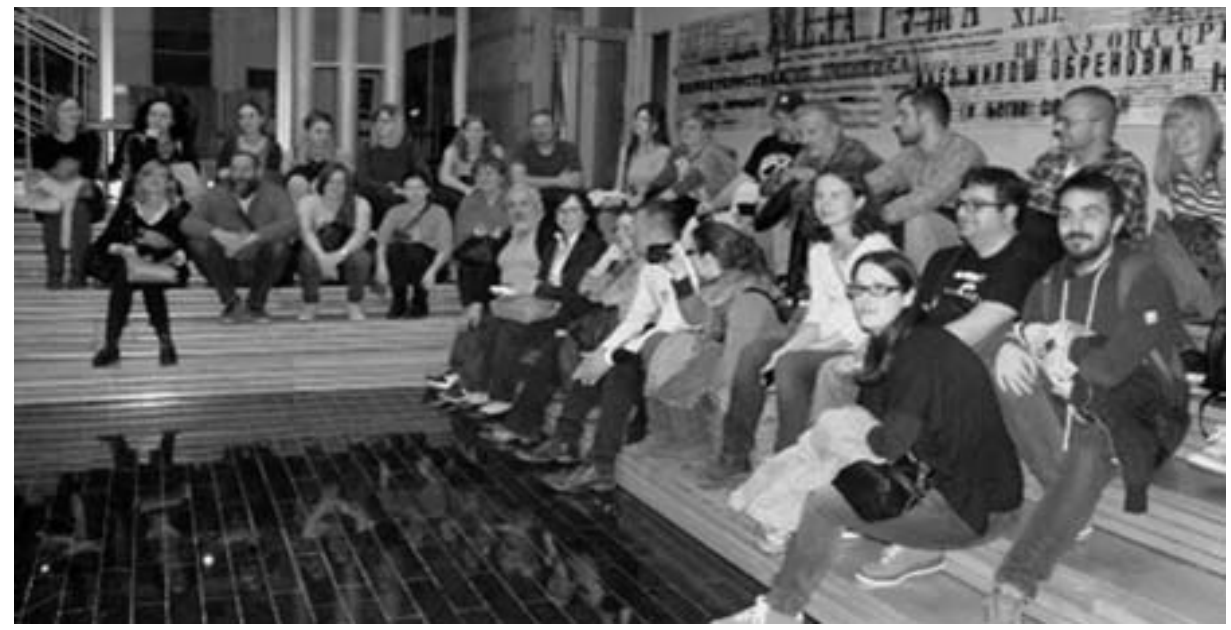

Slika 17. U Beogradu 2018. god. 


\section{Nagrade}

Veliki broj priznanja koja su tijekom godina dodijeljena članovima Društva pokazuje da je kvaliteta njihova rada prepoznata na lokalnoj i nacionalnoj razini.

Najveće priznaje u knjižničarskoj struci, Kukuljevićevu povelju, koju dodjeljuje HKD od 1968. godine kao oblik javnog priznanja knjižničnim djelatnicima za dugogodišnji rad i značajne rezultate na unapređenju knjižničarske djelatnosti, primilo je osam članova Društva (tablica 3).

Tablica 3. Dobitnici Kukuljevićeve povelje

\begin{tabular}{|l|c|}
\hline Dobitnici & godina \\
\hline Marija Malbaša & 1968. \\
\hline Vera Erl & 1996. \\
\hline Ljubica Radman & 1998. \\
\hline Silva Pavlinić & 2000. \\
\hline Kata Ivić & 2002. \\
\hline Dragutin Katalenac & 2006. \\
\hline Marina Vinaj & 2016. \\
\hline Sanja Galic & 2018. \\
\hline
\end{tabular}

Nagradu „Eva Verona“, koju od 1996. godine HKD dodjeljuje mladim i perspektivnim knjižničarima do trideset i pete godine za posebno zalaganje u radu, inovacije i promicanje knjižničarske struke, dobilo je dvanaest mladih knjižničara (tablica 4).

Tablica 4. Dobitnici Nagrade „Eva Verona“

\begin{tabular}{|l|c|}
\hline Dobitnici & godina \\
\hline Kornelija Petr & 1998. \\
\hline Andrea Božić & 2002. \\
\hline Renata Bošnjaković & 2004. \\
\hline Boris Badurina & 2006. \\
\hline Sanjica Faletar Tanacković & 2006. \\
\hline Maja Krtalić & 2008. \\
\hline Marija Kretić Nađ & 2010. \\
\hline Ivana Knežević & 2014. \\
\hline Klaudija Ladan & 2014. \\
\hline Tihomir Marojević & 2014. \\
\hline Ivana Martinović & 2014. \\
\hline Snježana Stanarević Katavić & 2016. \\
\hline
\end{tabular}


Redom Danice hrvatske s likom Marka Marulića, odlikovanjem Republike Hrvatske koje se dodjeljuje za osobite zasluge u kulturi, odlikovano je osam članova (tablica 5).

Tablica 5. Odlikovani Redom Danice hrvatske s likom Marka Marulića

\begin{tabular}{|l|c|}
\hline Odlikovani & godina \\
\hline Dragutin Katalenac & 1996. \\
\hline Jurica Buljan & 1997. \\
\hline Vera Erl & 1997. \\
\hline Antonija Kukuljica & 1997. \\
\hline Marija Bajt & 1999. \\
\hline Jasenka Bešlić & 1999. \\
\hline Grga Krajina & 1999. \\
\hline Ljubica Radman & 1999. \\
\hline
\end{tabular}

Spomen medaljom „Vukovar“ 1998. godine predsjednik Republike Hrvatske odlikovao je Antoniju Kukuljicu za djelatni doprinos mirnoj reintegraciji Hrvatskog Podunavlja u ustavno-pravni poredak Republike Hrvatske.

Priznanja za svoj rad na području knjižničarstva mr. sc. Vera Erl dobila je i izvan knjižničarske struke: 1975. godine povodom 100. obljetnice Narodne knjižnice i čitaonice Vinkovci dodijeljen joj je Orden rada sa srebrenom zvijezdom, ${ }^{53}$ a 2014. godine Vukovarsko-srijemska županija dodijelila joj je Nagradu za životno djelo za izniman doprinos u području znanosti, kulture i knjižničarstva te Grad Osijek Grb Grada Osijeka za izuzetan doprinos u području obrazovanja. ${ }^{54}$

Priznanje Knjižnica godine koje Hrvatsko knjižničarsko društvo dodjeljuje od 2012. godine za izvrsnost u svrhu poticanja kreativnosti, inovativnosti i unapređivanja kvalitete rada u hrvatskim knjižnicama, 2015. godine dobila je Općinska narodna knjižnica Drenovci, a 2018. godine Gradska knjižnica Beli Manastir (slika 18).

53 Usp. Radman, Lj. Mr.sc. V. Erl i Hrvatsko knjižničarsko društvo - Društvo knjižničara Slavonije i Baranje. // Knjižničarstvo XIII-XIV, 1-2(2009-2010), str. 36.

54 Usp. Izvješće o radu Društva knjižničara Slavonije, Baranje i Srijema 2014.-2015. [citirano: 2021-03-10]. Dostupno na: http://www.dksb.hr/dokumenti/izvjesca-o-radu/. 


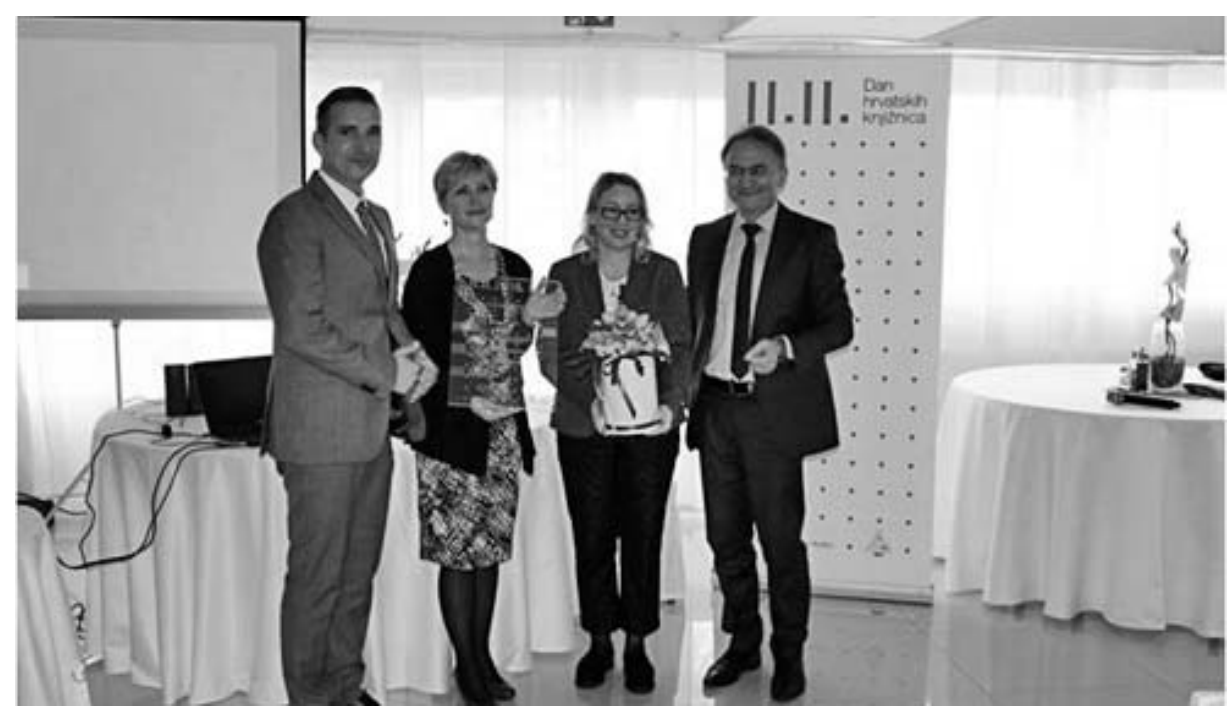

Slika 18. Knjižnica godine 2018. - Gradska knjižnica Beli Manastir ${ }^{55}$

Na redovnoj je Skupštini Društva u Orahovici 2004. godine, na prijedlog Upravnog odbora, utemeljena Povelja „Marija Malbaša“ kojom se nagrađuju najistaknutiji članovi za dugogodišnji rad u Društvu i značajne rezultate na unaprjeđivanju i promicanju ugleda Društva i knjižničarske struke. Nazvana je imenom prof. Marije Malbaše, ,istaknute knjižničarke i autorice Osječke bibliografije, posebno zaslužne za osnivanje Društva i razvoj knjižničarstva u Slavoniji i Ba-

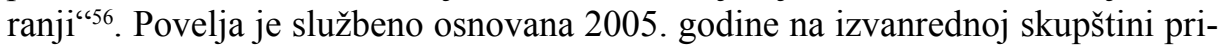
hvaćanjem Prijedloga pravilnika i poslovnika nagrade koje je izradila radna grupa (Ljuba Radman, Marica Galić, Vera Erl i Marina Vinaj). Dodjeljuje se svake dvije godine na Skupštini na prijedlog Ocjenjivačkog odbora. ${ }^{57}$ Izuzetno ponosne na nagradu koja nosi ime naše uvažene knjižničarke, svestrane kulturne djelatnice, nagradu je primilo devet dobitnica (tablica 6).

55 Dodjela priznanja u Kneževim Vinogradima. Na fotografiji slijeva nadesno: gradonačelnik grada Belog Manastira Tomislav Rob, ravnateljica Gradske knjižnice Beli Manastir Marija Kretić Nađ, predsjednica HKD-a Dijana Machala i državni tajnik Ministarstva kulture i medija Republike Hrvatske Ivica Poljičak.

56 Pravilnik o dodjeljivanju Povelje „Marija Malbaša“.[citirano: 2020-06-26]. Dostupno na:http://www.dksb.hr/povelja-m- malbasa/pravilnik/.

57 Rad Ocjenjivačkog odbora utvrđen je Poslovnikom Ocjenjivačkog odbora za dodjeljivanje Povelje „Marija Malbaša.“ Članice prvog Ocjenjivačkog odbora bile su: Silva Pavlinić (predsjednica Odbora), Tatjana Aparac-Jelušić, Emilija Pezer, Ljuba Radman i Mirjana Zandt. 
Tablica 6. Dobitnice Povelje „Marija Malbaša“

\begin{tabular}{|l|c|}
\hline Dobitnice & godina \\
\hline Nada Bojanić & 2006. \\
\hline Vera Erl & 2006. \\
\hline Silva Pavlinić (posthumno) & 2008. \\
\hline Ljubica Radman & 2010. \\
\hline Jasenka Bešlić & 2012. \\
\hline Emilija Pezer & 2014. \\
\hline Sanda Hasenay & 2016. \\
\hline Blaženka Pavlović-Radmanović & 2016. \\
\hline Ljiljana Krpeljević & 2019. \\
\hline
\end{tabular}

\section{Javnost rada Društva}

Javno se djelovanje Društva ostvaruje redovnim obavještavanjem članova Društva i javnosti o radu tijela Društva. Rad je Skupštine Društva javan, osim u slučajevima kada se na sjednici Skupštine raspravlja o podacima koji se smatraju poslovnom tajnom Društva ili kada to odluči većina članova Skupštine.

Predsjednica i tajnica Društva, kao i članovi Društva, brinu da knjižničarska struka na području Hrvatske dobije uvid u rad udruge, stoga u glasilu Društva, Vjesniku bibliotekara Hrvatske i HKD Novostima objavljuju priloge o radu Druš-

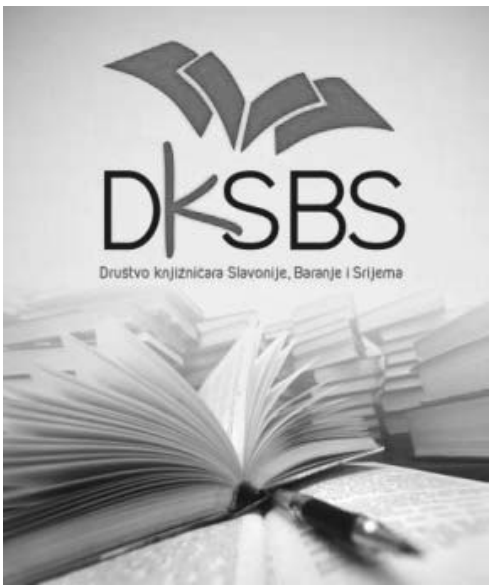

Slika 19. logo Društva tva i njegovih članova. Za Društvo je vrlo važno i upoznavanje lokalnog stanovništva, ali i šire javnosti s poslanjem i radom Udruge, stoga putem lokalnih medija kontinuirano obavještava javnost o raznim događanjima i stručnim manifestacijama koje se održavaju u organizaciji Društva. Javnosti Društva pridonose i mrežna stranica na adresi www. dksb.hr, kao i stranica na društvenoj mreži Facebook https://www.facebook.com/dkslavonijebaranjeisrijema, gdje je zainteresiranima omogućen pristup osnovnim informacijama o Društvu te obavijestima o novostima i događanjima u okviru Društva. U komunikaciji Društvo koristi logo (slika 19). 


\section{Prilagodba krizi u vrijeme pandemije bolesti COVID-19}

Kako su se pojedine knjižnice prilagođavale izazovima uzrokovanim pandemijom bolesti COVID-19, i Društvo je pratilo situaciju i svoje djelatnosti prilagodilo datom trenutku. Zbog nepovoljne epidemiološke situacije, planirana skupština za svibanj 2020. odgođena je za rujan te iste godine, ali se tada, zbog još lošije epidemiološke situacije, odustalo od fizičke i održana je 1. elektronička skupština.

Razočarani zbog nemogućnosti prikazivanja pripremljene izložbe članovima, digitalizirana su izdanja Društva te su na mrežnim stranicama objavljeni Rad Društva bibliotekara Slavonije i Baranje: 1975. - 1985..$^{58}$ i Spomenica Društva knjižničara Slavonije i Baranje: 1975. - 2005. ${ }^{59}$ Kako je svim članovima Spomenica bogat izvor informacija u svakodnevnom radu, kao i podsjetnik na lijepa prijateljstva, konačno je dostupna svima u digitalnom izdanju, pogotovo sada kada su smanjene aktivnosti Društva i mogućnosti druženja uživo.

S odgađanjem međunarodnih skupova i radionica oklijevalo se do posljednjeg trenutka, ali su se morali odgoditi oni koje Društvo svakako želi održati fizički, s nadom da će to biti moguće tijekom 2021. godine.

$\mathrm{Na}$ 45. Skupštini Hrvatskoga knjižničarskog društva održanoj 2020. godine, u okviru podteme Razvoj i perspektive djelovanja knjižničarskih društava na lokalnoj, nacionalnoj i međunarodnoj razini predstavljeno je i 45 godina rada Društva knjižničara Slavonije, Baranje i Srijema. Upravo je kriza uzrokovana bolešću COVID-19 onemogućila fizičko obilježavanje te važne obljetnice te se ono privremeno „preselilo“ u online okruženje, sa željom da će u 2021. godini ipak biti moguće okupljanje svih članova Društva.

\section{Plan rada i vizija budućnosti}

Kako bi bilo funkcionalno, nastavljajući dosadašnju dobro utemeljenu praksu, Društvo će nastaviti s radom upravnih i stručnih tijela. Na izbornoj skupštini u Dalju 2021. godine upriličit će se i naknadna fizička proslava značajne 45. obljetnice rada Društva. Časopis Knjižničarstvo i dalje će se unaprjeđivati, kao i organizirati stručni skupovi. Za tekuću 2021. godinu planiran je 4. okrugli stol: Zavičajni fondovi i zbirke u knjižnicama panonskoga prostora: mjesta susreta i suradnje $\mathrm{i}$ ciklus radionica Knjižnice za 21. stoljeće. Stručna predavanja aktualne problematike i predstavljanja stručnih publikacija uvijek su poželjna. Ne odustaje se ni od planiranog stručnog putovanja u Austriju, kada epidemiološka situacija dopusti, kao ni od razvoja međuinstitucionalne suradnje kad god za to bude prigode. $\mathrm{U}$

58 Rad Društva bibliotekara Slavonije i Baranje. Osijek, 1985. // ISSUU. [citirano: 2021-04-08]. Dostupno na: https://issuu.com/dksbs/docs/rad_dksbs_1975-1985.

59 Društvo knjižničara Slavonije i Baranje. Spomenica 1975-2005. // ISSUU. [citirano: 2021-0408]. Dostupno na: https://issuu.com/dksbs/docs/spomenica_dksbs_1975-2005. 
budućnosti Društvo i dalje planira nastavak i unaprjeđivanje postojeće suradnje s mađarskim kolegama, ali bi se veći naglasak trebao staviti na konkretne prijedloge i programe te putem Fondova Europske unije zajedno pokušati doći do sredstava te unaprijediti i hrvatsko i mađarsko knjižničarstvo. Prijavama na različite natječaje pokušat će se osigurati sredstva za što kvalitetniji i sadržajniji rad. Kvalitetnom će se programskom djelatnošću zasigurno privući novo članstvo. I dalje će se posebna pažnja posvetiti nakladničkoj djelatnosti. Poželjno bi bilo analizirati arhivsku građu i povodom 50. obljetnice rada objaviti 2. svezak Spomenice DKSBS: 2006. - 2025. Također je, još uvijek, neostvareni san objava tiskanog Vodiča kroz knjižnice Slavonije, Baranje i Srijema, što iziskuje silan trud entuzijasta pojedinaca i financijska sredstva.

\section{Zaključak}

Kvalitetu suvremenog demokratskog društva određuje djelovanje udruga i neprofitnih organizacija sa svrhom ostvarivanja javnog interesa bez profita. Knjižničarska društva unapređuju knjižničarsku struku i društvo općenito te zastupaju interese i prava knjižničnih djelatnika, ali i njihovih korisnika.

Stručna tijela Društva svojim radom omogućuju ostvarivanje planova i programa Društva. Od samog početka veliki je trud uložen na uključivanje što više članova u Društvo te je vidljivo povećanje broja članova, što se svakako može povezati i s osnivanjem novih knjižnica i otvaranjem novih radnih mjesta u ovoj regiji.

Nezaobilazno je spomenuti razdoblje Domovinskoga rata koji je značajno utjecao na djelovanje Društva. U tim teškim vremenima knjižničari su mogli samo otklanjati učinjene štete, prikupljati knjižnu građu za porušene i okupirane knjižnice, pisati i govoriti o stradanjima knjižnica, njenih djelatnika i fondova. Međutim, nakon ratnih godina ponovo se okupilo članstvo i Društvo se s velikim elanom uključilo u suvremene knjižničarske tokove.

Kako bi knjižničari Slavonije i Baranje bili u tijeku s promjenama u knjižničarstvu, usavršavali se i zajednički rješavali probleme s kojima se struka svakodnevno susreće, Društvo organizira stručne skupove, seminare, okrugle stolove i konferencije. Uspjehu rada pridonosi i dobra suradnja s Hrvatskim knjižničarskim društvom te srodnim udrugama i ustanovama.

Društvo je ostvarilo izvrsnu međunarodnu suradnju s Mađarskim knjižničarskim Društvom. Razmijenjena su iskustva i ukazano je na probleme s kojima se susreću knjižničari s obiju strana granice, a razvila se i prijateljska veza članova dviju knjižničarskih udruga. Društvo od 1997. godine objavljuje stručno glasilo Knjižničarstvo.

Izlaganja na skupovima prilike su za animiranje novih članova, međutim publika je ograničena na uži profesionalni krug. Kako bi se problematika knjižničarske struke učinila dostupnom široj javnosti i potaknuo interes zajednice, Društvo 
knjižničara Slavonije, Baranje i Srijema koristi javne medije, mrežne stranice i društvene mreže.

Jedan su od pokazatelja uspješnosti Društva brojne nagrade i priznanja kojima su pojedini članovi nagrađeni za svoja postignuća na području knjižničarstva, a time i u radu udruge.

Iako se knjižničarska struka susreće s nizom problema kao što su različiti statusi knjižničara u pojedinim tipovima knjižnica, nepriznavanje viših zvanja od strane osnivača, problemi knjižnica u sastavu u odnosu na matičnu instituciju itd., knjižničari su uporni u nakani očuvanja profesije.

Novi mediji i digitalno doba donose nove izazove. Unatoč najavama nestanka konvencionalne knjižnične građe, knjižničar - informacijski stručnjak nužna je spona između znanja, informacija, bez obzira na vrstu medija i korisnika. Upravo zbog toga Društvo knjižničara Slavonije, Baranje i Srijema ima iznimnu ulogu u očuvanju knjižničarske struke, a na najbolji je to način pokazalo 2020. godine tijekom pandemije bolesti COVID-19 kada njegove aktivnosti nisu zamrle, već se prilagodile i nastavile u online okruženju.

\section{LITERATURA}

About IFLA. [citirano: 2021-04-05]. Dostupno na: https://www.ifla.org/about.

[Dvadeseta] XX. redovna godišnja skupština Hrvatskoga bibliotekarskog društva. // Vjesnikbibliotekara Hrvatske 21, 1/4 (1975), str. 44.

FID // Hrvatska enciklopedija. Zagreb: Leksikografski zavod Miroslav Krleža, 1999. 2001. sv. 3. Str. 623-624.

Knjižničarstvo. [citirano: 2020-06-29]. Dostupno na: https://nova.knjiznicarstvo.com.hr.

Pavlinić, S. Društvo knjižničara Slavonije i Baranje. // Hrvatsko knjižničarskodruštvo: 14. III. 1940. - 14. III. 2000.: spomenica. Zagreb: Hrvatsko knjižničarskodruštvo, 2000. Str. 64-66.

Pismohrana Društva.Izvještaj o održanom godišnjem sastanku od 22. IV. 1967. Osijek: Podružnica Društva bibliotekara Hrvatske-Osijek, 1967.

Pismohrana Društva. Izvještaj o radu Podružnice Hrvatskog bibliotekarskog društva-Osijek od 21. III. 1973. do 21. V. 1975. godine. Osijek: Podružnica Društva bibliotekara Hrvatske-Osijek, 1975.

Pismohrana Društva.Opisno godišnje izvješće o radu DKSBS-a u razdoblju od 1. siječnja do 31. prosinca 2019. Osijek: Društvo knjižničara Slavonije, Baranje i Srijema, 2020 . 
Pismohrana Društva. Zapisnik sa Osnivačke Skupštine Društva bibliotekara Slavonije i Baranje koja je održanau Osijeku, 21. 05. 1975. god. Osijek: Društvo bibliotekara Slavonije i Baranje, 1975.

Pismohrana Društva. Zapisnik sa sastanka Inicijativnog odbora za osnivanje Društva bibliotekara Slavonije iBaranje održanog 16. V. 1975. u Gradskoj knjižnici Osijek. Osijek: Podružnica Društva bibliotekara Hrvatske-Osijek, 1975.

Povijesna crtica o Društvu. [citirano: 2020-06-04]. Dostupno na: http://www.dksb.hr/ povijest/.

Pravilnik o dodjeljivanju Povelje „Marija Malbaša“. [citirano: 2020-06-26]. Dostupno na: http://www.dksb.hr/povelja-m-malbasa/pravilnik/.

Rad Društva bibliotekara Slavonije i Baranje: 1975-1985. Osijek: Društvo bibliotekara Slavonije i Baranje, 1985.

Radman, Lj. Mr.sc. V. Erl i Hrvatsko knjižničarsko društvo - Društvo knjižničara Slavonije i Baranje. // Knjižničarstvo XIII-XIV, 1-2 (2009-2010), str. 34-36.

Regionalna društva.[citirano: 2020-06-03]. Dostupno na: https://www.hkdrustvo.hr/ hr/o_nama/regionalna_drustva/.

Registar udruga RH. [citirano: 2020-12-27]. Dostupno na: https://registri.uprava. hr/\#! udruga-detalji/swcBAAEAAQGxZHJ1xaF0dm8ga25qacW-bmnEjWFyYSBzbGF2b25pamUsIGJhcmFuamUgaSBzcmlqZW1hAAAAAAAAAAAAAAEBAW9p4gIB2oEC.

Spomenica Društva knjižničara Slavonije i Baranje: 1975.-2005. Osijek: Društvo knjižničara Slavonije i Baranje, 2009.

Statut Društva knjižničara Slavonije, Baranje i Srijema. [citirano: 2020-06-25]. Dostupno na: http://www.dksb.hr/dokumenti/statut/.

Statut Hrvatskog knjižničarskog društva. [citirano: 2021-03-01]. Dostupno na: http:// www.hkdrustvo.hr/hr/statut/.

Vinaj, M. Društvo knjižničara Slavonije, Baranje i Srijema. // Bibliotekar 2 (2017), str. 59-66.

Vodič kroz knjižnice Društva knjižničara Slavonije, Baranje i Srijema. [citirano: 202006-29]. Dostupno na:http://www.dksb.hr/knjiznice/.

Zabjan, A. Društvo knjižničara Slavonije i Baranje: osnutak, razvoj i djelovanje (1975.2007.).: diplomski rad; Zadar : Sveučilište u Zadru, Odjel za knjižničarstvo, Izvanredni diplomski sveučilišni studij Informacijske znanosti - knjižničarstvo, 2008.

Živković, D. Osnutak i prve godine rada: pogled u arhiv. // Hrvatsko knjižničarsko društvo: 14. III. 1940. - 14. III. 2000.: spomenica. Zagreb: Hrvatsko knjižničarsko društvo, 2000. Str. 9-16. 


\section{Prilog 1.}

\section{Popis magistarskih i doktorskih radova članova Društva}

\section{MAGISTARSKI RADOVI}

1. FIRINGER-Burić, Vesna. Muzeološka koncepcija i struktura Knjižnice Muzeja Slavonije Osijek. Zagreb: Sveučilište u Zagrebu, (CSBDIZ), 1981.

2. HARTH, Branka. Analiza strukture i organizacije matičnih datoteka postojećeg informacijskog sistema proizvodne organizacije i prijedlog prijelaza na bazu podataka. Zagreb: Sveučilište u Zagrebu, (CSBDIZ), 1981.

3. KOŠKI, Marija. Povijesni razvoj teorije predmetnog kataloga. Zagreb: Sveučilište u Zagrebu, (CSBDIZ), 1981.

4. RADMAN, Ljuba. Bibliotečna građa Knjižnice Centra za usmjereno obrazovanje „Braća Ribar" u Osijeku i njena uloga u ostvarivanju odgojno-obrazovnih i kulturnih zadataka u prošlosti, danas i narednom razdoblju. Zagreb: Sveučilište u Zagrebu, (CSBDIZ), 1981.

5. IVIĆ, Kata. Primjena sistemskog pristupa u definiranju bibliotečno-informacijskog sistema. Osijek: Ekonomski fakultet, 1981.

6. KOBAŠ, Pavao. Marketing u bibliotečno-informacijskoj djelatnosti. Beograd: Ekonomski fakultet, 1984.

7. ERL, Vera. Slavonija 1683.-1848. u zapisima suvremenika (Dokumentacijsko-informacijska analiza). Zagreb: Filozofski fakultet, 1989.

8. LOVRINČEVIĆ, Jasmina. Školska knjižnica kao jedan od čimbenika unapređivanja odgojno-obrazovnog procesa. Zagreb: Filozofski fakultet, 1994.

9. PETR, Kornelija. Korisnici i korištenje knjižničnih usluga u Knjižnici Pedagoškog fakulteta Sveučilišta Josipa Jurja Strossmayera u Osijeku. Zagreb: Filozofski fakultet, 1999.

10. VINAJ, Marina. Građa za bibliografiju osječkih novina 1848.-1945. Zagreb: Filozofski fakultet, 2001.

11. MOKRIŠ, Svjetlana. Model organizacije odjela periodike u knjižnici s dvojnom funkcijom. Zagreb: Filozofski fakultet, 2001.

12. ŠKORO, Marija. Upravljanje knjižnicom u uvjetima informacijske tehnologije. Osijek: Pravni fakultet, 2002.

13. RADIČEVIĆ, Vesna. Primjena autorskog prava u knjižnicama. Zagreb: Filozofski fakultet, 2003.

14. PAVLOVIĆ-Radmanović, Blaženka. Povijest franjevačkih knjižnica u Slavoniji. Zagreb: Filozofski fakultet, 2003. 
15. FALETAR Tanacković, Sanjica. Mogućnosti suradnje baštinskih ustanova. Zagreb: Filozofski fakultet, 2006.

16. MAJLINGER-Tanocki, Inge. Pristup arhivima narodnih knjižnica na internetu s posebnim osvrtom na sadržajnu analizu. Zagreb: Filozofski fakultet, 2012.

\section{DOKTORSKE DISERTACIJE}

17. BLAŽEK, Pavle. Djelovanje i djelo Miroslava Kraljevića. Beograd: Filološki fakultet, 1981.

18. IVIĆ, Kata. Izvori i analiza informacija u strategijskom planiranju i odlučivanju. Osijek: Ekonomski fakultet, 1994.

19. PETR, Kornelija. Kvalitativni pokazatelji uspješnosti akademskih knjižnica. Zagreb: Filozofski fakultet, 2004.

20. FALETAR Tanacković, Sanjica. Modeli suradnje hrvatskih baštinskih ustanova. Zagreb: Filozofski fakultet, 2009.

21. MOKRIŠ, Svjetlana. Novinske zbirke u regionalnom knjižničnom sustavu na primjeru Slavonije i Baranje: tehnički aspekti knjižničnog poslovanja i načini međusobnog povezivanja knjižnica u uvjetima suvremenog elektroničnog okruženja. Zagreb: Filozofski fakultet, 2009.

22. RADIČEVIĆ, Vesna. Pravo javne posudbe u knjižnicama u Hrvatskoj. Zagreb: Filozofski fakultet, 2009.

23. KRETIĆ-Nađ, Marija. Popularna kultura u Osječkome "Hrvatskom listu": (1920.1945.). Zagreb: Filozofski fakultet, 2011.

24. MARTINOVIĆ, Ivana. Slikovnica kao poticajni materijal za leksički razvoj djece u trećoj godini života. Osijek: Filozofski fakultet, 2011.

25. MIČUNOVIĆ, Milijana. Razvoj i primjena konceptualne metafore u jeziku suvremene znanosti: konceptualizacija prostora, vremena i stanja. Osijek: Filozofski fakultet, 2012.

26. VINAJ, Marina. Knjižna zbirka Prandau-Normann kao muzeološki fenomen. Zagreb: Filozofski fakultet, 2012.

27. ERL Šafar, Marija. Razvoj pokretnih knjižnica u Republici Hrvatskoj. Zagreb: Filozofski fakultet, 2013.

28. STANAREVIĆ Katavić, Snježana. Informacijske potrebe i obrasci informacijskog ponašanja oboljelih od rijetkih kroničnih bolesti u Republici Hrvatskoj. Zadar: Odjel za informacijske znanosti, 2013.

29. FELDVARI, Kristina. Okvir za izradu i dizajn tezaurusa za označivanje. Zadar: Odjel za informacijske znanosti, 2014. 
30. LACOVIĆ, Darko. Informacijske potrebe i ponašanja katoličkih svećenika pri traženju i korištenju informacija za pastoralni rad. Zadar: Odjel za informacijske znanosti, 2015.

31. BANDO, Irena. Analiza kulturne i javne djelatnosti u kurikulumima osnovnoškolskih knjižnica Slavonije i Baranje. Osijek: Sveučilište Josipa Jurja Strossmayera, Doktorska škola, 2017.

32. LUBINA, Tihana. Gimnazijska knjižna zbirka muzeja Slavonije. Osijek: Sveučilište Josipa Jurja Strossmayera, Doktorska škola, 2019.

33. ŠPOLJARIĆ Kizivat, Marijana. Organizacija i očuvanje zbirki legata u knjižnicama. Zadar: Odjel za informacijske znanosti, 2020. 